\title{
Employment, late-life work, retirement, and well-being in Europe and the United States
}

Milena Nikolova ${ }^{1,2^{*}}$ and Carol Graham ${ }^{1,2}$

\author{
* Correspondence: \\ mnikolov@umd.edu \\ ${ }^{1}$ The Brookings Institution, Washington, \\ DC 20036, USA \\ ${ }^{2}$ School of Public Policy, University \\ of Maryland, College Park, MD \\ 20742, USA
}

\begin{abstract}
Flexible work arrangements and retirement options provide one solution for the challenges of unemployment and underemployment, aging populations, and unsustainable public pension systems in welfare states around the world. We examine the relationships between well-being and job satisfaction on the one hand and employment status and retirement, on the other, using Gallup World Poll data for several European countries and the United States. We find that voluntary part-time workers are happier, experience less stress and anger, and have higher job satisfaction than other employees. Using statistical matching, we show that late-life workers under voluntary part-time or full-time arrangements have higher well-being than retirees. There is no well-being premium for involuntary late-life work and self-employment compared to retirement, however. Our findings inform ongoing debates about the optimal retirement age and the fiscal burdens of public pension systems.

JEL codes: J14; J21; J26; J28; 131; Z18
\end{abstract}

Keywords: Subjective well-being; Job satisfaction; Employment; Voluntary part-time work; Retirement; Propensity score matching

\section{Introduction}

Unemployment and underemployment, aging populations, and unsustainable retirement policies, among others, pose serious challenges for welfare states around the world (Derviş 2013). The global financial crisis and its uneven recovery have heightened these issues, with the new labor force entrants taking the hardest hit. In 2012, the youth unemployment rate (ages 15-24) peaked to 53 percent in Spain and nearly 40 percent in Portugal, compared with 16 percent in the U.S. (OECD 2013). The young are disproportionately affected even in countries with relatively lower unemployment rates such as the U.S. (Burtless 2013), and the long-term effects of delayed labor force entrance could be especially harmful. On the other end of the age distribution, unsustainable fiscal deficits in many countries are forcing the reconsideration of public pensions and retirement schemes. Given higher life expectancies and low fertility rates in the developed world, moreover, the share of older workers will continue to grow.

One solution to these challenges, recently proposed by Kemal Derviş (2013), entails more individual choice regarding employment, including a scheme whereby older workers gradually lower their working hours but remain in the labor force (and pay taxes) until the age of $70^{1}$. Gradual retirement could be beneficial for governments, employers, and workers. Specifically, from a public finance perspective, phased-in 
retirement will likely increase tax revenues and reduce expenditures on pensions and retirement benefits. Moreover, while European employers view older workers as a burden (vanDalen et al. 2010), late-life employees are valuable to organizations as they have experience and competence. Burtless (2013), for example, documents the pay premium that latelife workers receive compared to their younger counterparts in the U.S., suggesting that older workers are more productive. Finally, late-life work can be beneficial for older employees as well. Research shows that late-life work has a positive effect on well-being in the U.S. (Calvo 2006) while involuntary retirement decreases well-being in the U.S. and Germany (Bonsang and Klein 2012; Calvo et al. 2009).

From a general equilibrium perspective, phased-in retirement constitutes an increase in the supply of older workers, which decreases their wages. As a result, if young and old workers are substitutes, employers may prefer to hire older workers which in turn reduces both the number of young people employed and their wages ${ }^{2}$. The fiscal contributions from extended retirement could be used to mitigate any harmful effects on younger workers through apprenticeships and training programs. While general equilibrium analyses on the effects of altering employment and retirement schemes rarely factor in subjective well-being, work arrangements have differential effects for the happy and unhappy people, moreover. ${ }^{3}$

A priori, the potential individual well-being effects of changing employment and retirement policies are ambiguous. The results from smaller-scale experiments or experiences with altering these schemes from other countries may be misleading as scale and context matter. We therefore attempt to inform the policy discussions, as outlined by Derviş (2013) and in Aaron and Burtless (2013), among others, by furnishing insights from the relatively novel "science" of well-being measurement. Specifically, we explore the relationship between voluntary part-time employment, late-life work, and retirement and various well-being dimensions and job satisfaction using individual-level data from the Gallup World Poll (GWP) for a number of European countries and the U.S.

We build on several strands of research. It is well-established that the unemployed have lower well-being levels than the employed in virtually every context that relationship has been studied (Clark et al. 2001; Winkelmann and Winkelmann 1998; Hetschko et al. 2013; DiTella et al. 2001; Clark and Oswald 1994; Ravallion and Lokshin 2001). In European countries, for example, the jobless experience a life satisfaction reduction of 0.33 (on a scale of 1 "not at all satisfied" to 4 "very satisfied") (DiTella et al. 2001) and even if compensated for the income loss, the unemployed would still be less happy compared to identical employed counterparts (Frey 2008). Clark et al. (2001) and Clark (2003) show, moreover, that unlike other adverse life events, past unemployment has lasting perverse effects on subjective well-being. The psychology literature also documents the "scarring" effects on the well-being of the long-term unemployed (Lucas 2007; Lucas et al. 2004). Indeed, long-term unemployment stands in contrast to other major life-events, such as divorce and physical injury, to which individuals adapt (i.e., return to their baseline well-being levels).

Retirees' well-being, meanwhile, varies across countries because of different retirement norms and the generosity of public pensions. Research shows that the retired are more satisfied with their lives than the average in the U.S., less satisfied than the average in Russia, and the same as the average in Latin America (Graham and Pettinato 2002; Graham 2009) ${ }^{4}$. A study of male Canadian retirees demonstrates that the relationship between life satisfaction and retirement remains relatively stable over the course of retirement (Gall et al. 1997) ${ }^{5}$. Early on, recent retirees experience a life satisfaction boost 
and retirees' perceptions of health, satisfaction with activity and overall life satisfaction persist 6-7 years post-retirement. A study using panel data from the U.S. shows, however, that retirement can lead to three psychological well-being patterns (Wang 2007). The majority of retirees maintain the same levels of pre-retirement well-being throughout their retirement years by sticking to their patterns of thought and behavior. A second group of retirees, especially those who disliked their jobs, experience a gain in psychological well-being which lasts throughout their retirement years. Finally, a third group of retirees experience a sharp decline in well-being due to loss of identity and status followed by a well-being recovery. Much less is known, however, about how different working and retirement arrangements - such as part-time work and flexible employment- correlate with well-being for older workers (as well as for other age cohorts).

Furthermore, employment arrangements and job types play a role for subjective wellbeing (SWB) comparisons. Knabe and Rätzel (2010) show that those who are unemployed but expecting to return to the labor force soon are no less happy than those who are employed in jobs with medium job security, and are in fact happier than those with minimal job security ${ }^{6}$. Several studies find that the self-employed are more satisfied with their jobs than those working for an employer in the OECD countries (Dolan et al. 2008; Binder and Coad 2011) and in other contexts (Benz and Frey 2008). In contrast, while mixed, the evidence from Latin America seems to suggest that the self-employed are less satisfied with their lives and jobs, due to the precarious nature of self-employment in the region self-employment there is more likely to be involuntary and in the informal sector (Graham and Pettinato 2002; Graham and Felton 2006). Indeed, of the self-employed in Latin America, only business owners are more satisfied with their lives, incomes, and jobs, while the self-employed in more precarious occupations, such as farmers, fishermen, and informal employees, are less satisfied than the average (Aguilar et al. 2013).

Moreover, social norms related to employment mediate the employment-SWB relationship (Hetschko et al. 2013). While the unemployed are unhappier than the employed, the well-being effects are mitigated by the local unemployment level or norms about the generosity of the welfare system. For example, the unemployed in Britain are less unhappy when the regional unemployment rate, which approximates the strength of the social norm, is higher (Clark and Oswald 1994; Clark 2003; Shields and Price 2005). This result holds across different countries such as Australia (Shields et al. 2009), South Africa (Powdthavee 2007), Germany (Clark et al. 2010), and Russia (Eggers et al. 2006). For Russia, Eggers et al. (2006) demonstrate that high regional unemployment rates mitigate the individual well-being effects of unemployment and precarious employment and Grogan and Koka (2013) find that men face stigma in some non-market activities, suggesting that the effects of unemployment on SWB are more severe for men than for women. Based on research in Swiss cantons, moreover, Stutzer and Lalive (2004), show that the extent of canton-level support for unemployment benefits mediates the well-being gap between the unemployed and the employed. The unemployed who transition into retirement realize gains in life satisfaction precisely because they enter into a phase in life when working is unimportant (Hetschko et al. 2013).

In addition, scholars distinguish between hedonic and evaluative well-being (Graham 2012; Kahneman and Krueger 2006; Kahneman and Deaton 2010). Evaluative well-being survey items capture how people assess their lives as a whole, through general life satisfaction questions, or via the Cantril ladder question, which asks respondents to 
compare their life to the best possible life they can imagine, based on an eleven-point scale or ladder, where zero is their worst possible life and ten is their best possible life. Hedonic well-being, in contrast, is about people's affective states and encompasses day-to-day positive and negative emotions related to work commutes, one's immediate health state, job quality, and others (Graham 2012). Hedonic well-being metrics include both positive affect (e.g., smiling, experiencing happiness or joy) and negative affect (e.g., experiencing worry, sadness, anger, or stress).

Looking at both evaluative and hedonic well-being dimensions is particularly relevant in the case of employment and late-life work. For example, research shows that the unemployed have lower evaluative well-being levels (e.g., life satisfaction) than the employed but experience similar levels of positive and negative affect: while the jobless suffer consumption losses, these are partially offset by having more leisure time (Knabe et al. 2010). Furthermore, what a person expects to achieve in the future may be as important as current circumstances. Some people are in work arrangements because of what they want to achieve over their life course, rather than because they make their day-to-day living more pleasant. The balance between such objectives can change over the life course, moreover. While people may choose arrangements which enhance their daily living, at least temporarily, at the expense of career objectives, daily experiences can affect long-term objectives. Krueger et al. (2011) find, for instance, that the time spent looking for jobs is the saddest part of the day for the unemployed, and the longer those times last, the higher the likelihood that they cease the job search.

Building on the extant literature, we pose two research questions: (i) What is the relationship between employment status, work arrangements, and SWB (including job satisfaction)? and (ii) Is there an additional well-being effect for late-life workers? Our main contribution to the existing knowledge is the detailed exploration of the relationship between voluntary part-time work and different subjective well-being and job satisfaction dimensions, especially as related to late-life work. We find that voluntary part-time workers are happier, experience less stress and anger, and are more satisfied with their work than other workers. In addition, the propensity score matching results show that older workers who remain in the labor force under voluntary part-time or full-time arrangements have higher well-being than comparable retirees.

Different employment and retirement schemes may be better suited for people depending on their career objectives, innate well-being levels, and on where they are in the life cycle. Understanding how employment, retirement, and late-life work relate to well-being can contribute to ongoing public policy discussions in the U.S., Europe, and beyond. Given aging populations and the increasing role of work in retirement in several countries, understanding the well-being effects of flexible work arrangements such as late-life work may increase in relevance. Employment and late-life work can provide social contacts and interactions, personal growth, autonomy, and sense of purpose. The latter may be particularly relevant for older cohorts when the opportunities for active engagement decrease (Fisher, 1995).

\section{Data and variables}

The analysis sample comprises: France, Germany, Greece, Italy, Portugal, Spain, Sweden, Turkey, United States, and the United Kingdom. These countries represent 
a range of welfare state programs, tax administration systems, and cultural and institutional norms.

The data span 2009-2012 and are from the Gallup World Poll (GWP), which is an annual survey run by the Gallup organization in 160 countries, representing more than 98 percent of the world's adult population. GWP is probability-based and nationally representative (of populations aged 15 and over), polling about 1,000 individuals in each country, with samples ranging from about 500 in Puerto Rico to 4,000 in China, India, and Russia. The data are collected using telephone or in-person interviews using the same survey methodology across countries, making results comparable cross-sectionally and over time. The surveys were conducted via landline or cellular phone in France, Germany, Italy, Portugal, Spain, Sweden, United States, and United Kingdom. The data were collected via face-to-face interviews in Turkey and Greece. Because different respondents are polled each year, we have pooled cross-sections rather than a panel.

There is now a wide consensus that SWB metrics are valid, reliable, and psychometrically sound (Diener et al. 2012; Diener et al. 1999) and comparable across countries (Helliwell et al. 2010). Still, we recognize and attempt to correct for certain methodological issues. Research from the UK, for example, indicates that respondents are significantly more likely to report lower life satisfaction and happiness and higher anxiety in person than over the phone (Dolan and Kavetsos 2012). As the differences in interview mode are at the country level, country dummies in our regressions should capture this bias. ${ }^{7}$

We use a range of dependent variables to investigate the complex effects of employment and retirement on well-being. We measure evaluative well-being with the best possible life (BPL) question, and include measures of both positive and negative hedonic affect. For the first hedonic dimension, we use a binary indicator about experiencing happiness the day before, and for the second, we use separate variables about experiencing stress and anger the previous day, as the correlates for stress and anger often differ. Research across a range of disciplines finds that the stress associated with positive career advancement is not linked to negative health outcomes, but stress associated with circumstances beyond one's control is associated with shorter life spans (Velasquez-Manoff 2013) ${ }^{8}$. Studies also suggest that the process of acquiring freedom and capabilities often correlates with higher levels of evaluative well-being and higher levels of stress at the same time (Graham and Nikolova 2013).

Similarly to evaluative and hedonic subjective well-being, we investigate whether job satisfaction has hedonic and evaluative aspects. The few extant studies on the link between meaningful work and job satisfaction (Erdogan et al. 2012) show that people value interesting work and autonomy (i.e., the process of work) not because they lead to higher incomes but because they are important procedural aspects of work (Benz and Frey 2008). General job satisfaction questions likely capture day-to-day aspects of one's work life, while questions about whether one's job is the ideal one for them are more about their career path as a whole and are more likely to be reflective of eudemonic aspects.

Our focal independent variables are the individual-level employment status indicators, which Gallup included as part of the GWP starting in 2009. The employment data are collected using identical questions and standardized calculations enabling the comparison of employment statistics across countries and over time. Based on a series of questions about employment and work, Gallup researchers classify individuals in one of six employment categories: employed full-time for an employer; employed full-time for self; employed 
part-time, do not want to work full-time (i.e., voluntarily employed part-time); employed part-time, want to work full-time (i.e., involuntarily employed part-time); unemployed; out of the work force. The dataset distinguishes between voluntary and involuntary part-time work thus allowing us to account for individual choice regarding working time.

Those who are employed full-time (either for an employer or for self) work for at least 30 hours a week, while part-time work is less than 30 hours a week. The unemployed are those who reported that they did not work in the past seven days but were actively looking for a job and were able to begin work. The "out of the work force" category includes respondents who are not employed, are not looking for work, and/or are not able to start work. Such respondents may be homemakers, retired, students, and disabled individuals.

\section{Method}

We first used regression analysis to explore the relationship between employment status and SWB (including job satisfaction). We focused on whether and how different SWB dimensions relate to employment status and how this relationship varies by age. The dependent variables are: Best Possible Life (BPL), experienced happiness yesterday; job satisfaction; whether the respondent thinks her current job is her ideal job; experienced stress yesterday and experienced anger yesterday. All regressions are for 2009-2012 as there are no individual-level employment status data prior to 2009. When BPL is the dependent variable, we use an ordered logit specification and logits for the binary metrics.

Our basic specification explored the well-being/job satisfaction $Y$ of individual $i$, in year $t$, residing in country $c$, conditioned on the usual socioeconomic and demographic traits:

$$
\mathrm{Y}_{\text {itc }}=\alpha_{1} \mathrm{X}_{1 \mathrm{itc}}+\alpha_{2} \mathrm{X}_{2 \mathrm{itc}}+\alpha_{3} \mathrm{X}_{3 \mathrm{itc}}+\alpha_{4} \mathrm{X}_{4 \mathrm{itc}}+\alpha_{5} \mathrm{X}_{5 \mathrm{itc}}+\beta^{\prime} \mathrm{T}_{\mathrm{itc}}^{\prime}+\gamma^{\prime} Z_{\text {itc }}^{\prime}+k_{c}+\mathrm{\tau}_{t}+\varepsilon_{\text {itc }}
$$

where $\mathrm{X}_{1 \mathrm{itc}}-\mathrm{X}_{5 \mathrm{itc}}$ are the employment status variables (with the reference category being the full-time employees), $T^{\prime}$ itc is a vector of observed individual-level variables such as gender, age, marital status, income and others, $\mathrm{Z}^{\prime}$ itc is a vector of person-specific observed household-level variables such as household size, household location (i.e., rural or urban), and others; $\kappa_{\mathrm{c}}$ are country dummies, $\tau_{\mathrm{t}}$ are time dummies (year of survey), and $\varepsilon_{\mathrm{itc}}$ is the stochastic error term.

Second, to study the nuances of the SWB-employment relationship across age groups, in separate regressions, we add interaction terms (of age cohorts and employment categories). We included the following age groups: under 45 years of age; ages 46-65; and age 66 and older. The reference category for all interactions is the young.

Third, we employ propensity score matching (PSM) to compare retired individuals with observably similar late-life workers, as a means to assess the effect of retirement on well-being. Self-selection and endogeneity are the two main methodological problems related to discerning the causal effects of retirement and employment status on well-being. First, self-selection relates to the fact that those who choose late-life work or work under flexible employment arrangements (e.g., voluntary part-time work) may be unobservably different from those who select into retirement or those who work under traditional employment arrangements. For example, late-life workers may have different skills and motivation or face different levels of family pressure than those who choose to retire. Second, the direction of causality between happiness and employment could run 
both ways: different SWB levels may influence decisions about retirement and employment and employment and retirement affect well-being. We use the PSM technique in an attempt to mitigate these issues. While it controls for selections on observables, is semiparametric, and does not require assumptions for the outcome equation or the error term, PSM may not eliminate all bias; it demands sufficient data to pick the right pre-treatment covariates ${ }^{9}$; and using a small sample may yield incorrect estimates (Peikes et al. 2008). Given the unavailability of experimental or panel data, PSM is the best available alternative in our case. ${ }^{10}$

When deciding to retire or continue working, an individual $i$ considers whether the expected utility of retirement $\left(\mathrm{U}^{\mathrm{R}}\right)$ is greater than the expected utility of late-life work $\left(\mathrm{U}^{\mathrm{L}}\right)$ and retires if $\mathrm{U}^{\mathrm{R}}>\mathrm{U}^{\mathrm{L}}$ (Latif 2011). In addition, latent retirement behavior is given by $R^{*}=\eta Z+\varepsilon$, where $R=1$ if $R^{*}>0$ and $R=0$ if $R^{*} \leq 0, Z$ is a vector of individual characteristics determining retirement, and $\varepsilon$ is the error term.

Given the binary treatment indicator $R$ and the vector $\mathrm{Z}, Y_{i}\left(R_{i}\right)$ is the potential SWB outcome for each individual $i=1, \ldots, N$, where $\mathrm{N}$ is the total population of retirement age. The propensity score is $\mathrm{P}(\mathrm{Z})=\operatorname{Pr}(\mathrm{P}=1 \mid \mathrm{Z})$ (i.e., the conditional probability of retiring) and the PSM estimator for the average treatment effect (ATT) is (Caliendo and Kopeinig 2008):

$$
\tau_{\mathrm{ATT}}=\mathrm{E}_{\mathrm{P}(\mathrm{Z}) \mid \mathrm{R}=1}\{\mathrm{E}[\mathrm{Y}(1) \mid \mathrm{R}=1, \mathrm{P}(\mathrm{Z})]-\mathrm{E}[\mathrm{Y}(0) \mid \mathrm{R}=0, \mathrm{P}(\mathrm{Z})]\}
$$

The estimator is based on the following assumptions:

\section{Unconfoundedness for controls}

$\mathrm{Y}(0) \sqcup \mathrm{R} \mid \mathrm{Z}$

We assume that all relevant differences between retirees and non-retirees are captured in the $\mathrm{Z}$ variables. Thus, any systematic differences in the SWB outcomes between retirees and late-life workers with the same values for the covariates are due to retirement. While this is a rather strong assumption, it is fundamentally untestable.

\section{Weak overlap/common support}

$$
\mathrm{P}(\mathrm{R}=1 \mid \mathrm{Z})<1
$$

This assumption implies that persons with the same characteristics have a positive probability of being both retirees and non-retirees. The balancing tests for the covariates for the BPL outcome are available in Table 1. We also calculated the standardized bias before and after matching (Table 2). The goal of matching is to create statistically insignificant differences between the treatment and control samples and a mean bias of 0 .

Finally, the logit specification for calculating the propensity scores to match the treatment and controls is:

$$
\mathrm{R}_{\mathrm{i}}=\alpha_{1}+\beta^{\mathrm{R}} \mathrm{Z}_{\mathrm{i}}+\varepsilon_{\mathrm{i}}
$$

Our matching covariates are: age, gender, marital status, an interaction term for marriage and gender, education, religiosity, country, and year ${ }^{11}$. As Burtless (2013) shows, more educated older workers are also more likely to choose to remain in the labor force rather than retire. We control for this selection problem by including education as a matching covariate. These were the only variables that satisfied the balancing property and produced observably similar matches. We cannot match on variables that could be influenced 
Table 1 Balancing Tests, Matching Retirees with Non-Retirees, Best Possible Life Outcome

\begin{tabular}{lccccc}
\hline \multicolumn{7}{c}{ Control group: voluntary part-time workers } \\
\hline & Treatment & Control & Standardized bias & t-stat & p-value \\
\hline Age & 63.417 & 63.619 & -1.600 & -0.190 & 0.852 \\
Female (1=Yes) & 0.669 & 0.655 & 3.000 & 0.250 & 0.801 \\
Married (1=Yes) & 0.655 & 0.748 & -19.200 & -1.710 & 0.089 \\
Married and gender interaction & 0.439 & 0.460 & -4.500 & -0.360 & 0.719 \\
High school education or higher (1=Yes) & 0.216 & 0.237 & -5.100 & -0.430 & 0.669 \\
Religion important (1=Yes) & 0.554 & 0.547 & 1.500 & 0.120 & 0.904 \\
Country and year group & 19.129 & 19.129 & 0.000 & 0.000 & 1.000 \\
\hline Average bias & \multicolumn{7}{c}{ Before } & $\mathbf{4 4 . 5 0 3}$ & & \\
& After & $\mathbf{4 . 9 8 3}$ & &
\end{tabular}

\begin{tabular}{lccccc}
\hline \multicolumn{7}{c}{ Control group: full-time employees } \\
\hline & Treatment & Control & Standardized bias & t-stat & p-value \\
\hline Age & 56.796 & 57.022 & -2.200 & -0.290 & 0.768 \\
Female (1=Yes) & 0.597 & 0.571 & 5.400 & 0.570 & 0.568 \\
Married (1=Yes) & 0.677 & 0.708 & -6.300 & -0.710 & 0.477 \\
Married and gender interaction & 0.354 & 0.341 & 2.900 & 0.300 & 0.768 \\
High school education or higher (1=Yes) & 0.181 & 0.190 & -2.100 & -0.240 & 0.809 \\
Religion important (1=Yes) & 0.558 & 0.504 & 10.800 & 1.130 & 0.259 \\
Country and year group & 20.664 & 20.664 & 0.000 & 0.000 & 1.000 \\
\hline Average bias & \multicolumn{7}{c}{ Before } & $\mathbf{5 5 . 7 0 8}$ & \\
& After & $\mathbf{4 . 2 4 7}$ & \\
\hline
\end{tabular}

\begin{tabular}{lccccc}
\hline \multicolumn{7}{c}{ Control group: self-employed } \\
\hline & Treatment & Control & Standardized bias & t-stat & p-value \\
\hline Age & 59.438 & 59.705 & -2.400 & -0.210 & 0.832 \\
Female (1=Yes) & 0.375 & 0.375 & 0.000 & 0.000 & 1.000 \\
Married (1=Yes) & 0.616 & 0.705 & -18.600 & -1.410 & 0.160 \\
Married and Gender Interaction & 0.143 & 0.232 & -20.500 & -1.720 & 0.088 \\
High School Education or Higher (1=Yes) & 0.152 & 0.152 & 0.000 & 0.000 & 1.000 \\
Religion Important (1=Yes) & 0.741 & 0.688 & 10.800 & 0.880 & 0.377 \\
Country and Year Group & 24.071 & 24.071 & 0.000 & 0.000 & 1.000 \\
\hline Average bias & & Before & $\mathbf{5 1 . 6 4 5}$ & & \\
& After & $\mathbf{7 . 4 7 7}$ & &
\end{tabular}

\begin{tabular}{lccccc}
\hline \multicolumn{7}{c}{ Control group: involuntary part-time workers } \\
\hline & Treatment & Control & Standardized bias & t-stat & p-value \\
\hline Age & 61.274 & 61.613 & -2.800 & -0.180 & 0.854 \\
Female $(1=$ Yes) & 0.565 & 0.548 & 3.300 & 0.180 & 0.858 \\
Married (1=Yes) & 0.710 & 0.677 & 6.500 & 0.390 & 0.700 \\
Married and gender interaction & 0.323 & 0.290 & 7.000 & 0.390 & 0.700 \\
High school education or higher (1=Yes) & 0.177 & 0.210 & -8.100 & -0.450 & 0.653
\end{tabular}


Table 1 Balancing Tests, Matching Retirees with Non-Retirees, Best Possible Life Outcome (Continued)

\begin{tabular}{lccccr}
\hline Religion important (1=Yes) & 0.629 & 0.581 & 9.800 & 0.550 & 0.585 \\
Country and year group & 16.355 & 16.355 & 0.000 & 0.000 & 1.000 \\
\hline Average bias & & Before & $\mathbf{4 6 . 7 3 8}$ & & \\
& & After & $\mathbf{5 . 3 4 4}$ & & \\
\hline
\end{tabular}

Source: Gallup World Poll, 2009-2010.

Notes: Summary of results from caliper propensity score matching. The treatment group is the group of retirees. The control group is the voluntary part-time workers in the top panel, followed by the full-time employees, the self-employed, and the part-time workers in the bottom panel. Covariates used for matching (and satisfying the balancing property) are: age, gender, whether the respondent is married, an interaction term for marriage and gender, whether the respondent has at least high school education, whether religion is important in the respondent's life, country, and year.

by the treatment (Todd 2006; Heinrich et al. 2010) such as income (as it presumably decreases during retirement), or the number of children in the household and household size (as increases/decreases in the composition of these are possible in retirement - e.g., the birth of a grandchild). We force exact matches within year and county of residence. Total bias reduction with PSM is possible by using a large number of covariates or by having knowledge of the exact covariates that influence the selection process (Steiner et al. 2010). In choosing the matching covariates, we are limited by data availability, the restriction that the treatment cannot influence the matching variables, and the fact that we have imperfect knowledge of selection into retirement and employment arrangements. As a result, the matching procedure is imperfect and unlikely to account for all selection bias and the results should be treated with caution. Moreover, the goal of using PSM is not to perfectly capture the selection process but to create treatment and comparison groups which are similar along observable characteristics (Steiner et al. 2011). In other words, we aim to capture selection bias using proxies even if the best variables that capture selection are not available (Steiner et al. 2010).

\section{Descriptive statistics}

\section{1) Employment status}

Table 3 shows that about a third of all respondents in the sample were employed full-time working for an employer, an additional 6 percent were self-employed, 4 percent were unemployed, and 44 percent were out of the work force. Roughly 8 percent reported that they worked less than 30 hours a week but did not want to work more than that, while 4 percent worked part-time but wanted to be employed full-time. As expected, voluntary part-time employment varies by gender (not shown). Specifically, 10.9 percent of men and 5.3 percent of women were voluntarily employed part-time, which constitutes a statistically significant difference of 5.6 percentage points.

In addition to the general trends, the employment statistics vary by country (Table 3 ). The UK and Germany had the largest proportion of voluntarily employed part-time workers (11 percent), while Greece and Portugal had the lowest (3 percent). The U.S. and Spain had the largest proportion of respondents who said that they were employed part-time but wanted to work full-time (7 percent) among all countries in the sample. Sweden's proportion of full-time workers (51 percent) was the greatest among countries in the sample, while Turkey's, Greece's, and Italy's was the lowest (25 percent each). Finally, respondents in Spain were most likely group to report that they were unemployed 
Table 2 Mean Standardized Bias, Matching Retirees with Non-Retirees, All Well-being Outcomes

\begin{tabular}{|c|c|c|}
\hline \multicolumn{3}{|c|}{ Control group: voluntary part-time workers } \\
\hline & Before & $\overline{\text { After }}$ \\
\hline $\mathrm{BPL}$ & 44.503 & 4.983 \\
\hline Experienced happiness yesterday & 44.467 & 5.071 \\
\hline Smiled a lot yesterday & 44.719 & 3.950 \\
\hline Experienced stress yesterday & 44.650 & 5.036 \\
\hline Experienced anger yesterday & 44.661 & 4.308 \\
\hline Satisfied with personal health & 44.516 & 4.889 \\
\hline Satisfied with freedom & 43.489 & 5.505 \\
\hline \multicolumn{3}{|c|}{ Control group: full-time employees } \\
\hline & Before & After \\
\hline$\overline{\mathrm{BPL}}$ & 55.708 & 4.247 \\
\hline Experienced happiness yesterday & 55.900 & 4.580 \\
\hline Smiled a lot yesterday & 55.940 & 4.698 \\
\hline Experienced stress yesterday & 56.100 & 4.319 \\
\hline Experienced anger yesterday & 56.011 & 4.337 \\
\hline Satisfied with personal health & 55.875 & 4.299 \\
\hline Satisfied with freedom & 54.583 & 4.719 \\
\hline \multicolumn{3}{|c|}{ Control group: self-employed } \\
\hline & Before & After \\
\hline $\mathrm{BPL}$ & 51.645 & 7.477 \\
\hline Experienced happiness yesterday & 52.056 & 8.214 \\
\hline Smiled a lot yesterday & 51.887 & 7.539 \\
\hline Experienced stress yesterday & 52.054 & 7.614 \\
\hline Experienced anger yesterday & 51.954 & 7.545 \\
\hline Satisfied with personal health & 51.987 & 7.487 \\
\hline Satisfied with freedom & 49.682 & 6.490 \\
\hline \multicolumn{3}{|c|}{ Control group: involuntary part-time workers } \\
\hline & Before & After \\
\hline $\mathrm{BPL}$ & 46.738 & 5.344 \\
\hline Experienced happiness yesterday & 46.935 & 5.435 \\
\hline Smiled a lot yesterday & 46.906 & 4.131 \\
\hline Experienced stress yesterday & 46.950 & 5.346 \\
\hline Experienced anger yesterday & 46.878 & 5.345 \\
\hline Satisfied with personal health & 46.581 & 6.592 \\
\hline Satisfied with freedom & 45.993 & 5.082 \\
\hline
\end{tabular}

Source: Gallup World Poll, 2009-2010.

Notes: Summary of results from caliper propensity score matching. The treatment group is the group of retirees. The control group is the voluntary part-time workers in the top panel, followed by the full-time employees, the self-employed, and the part-time workers in the bottom panel. Covariates used for matching (and satisfying the balancing property) are: age, gender, whether the respondent is married, an interaction term for marriage and gender, whether the respondent has at least high school education, whether religion is important in the respondent's life, country, and year.

(12 percent) while those in Germany were the least likely ( 3 percent). These differences suggest divergent norms about the acceptability of part-time work status, as well as labor market conditions, differences which will also be reflected in our regression results. 
Table 3 Employment status, 2009-2012

\begin{tabular}{|c|c|c|c|c|c|c|c|c|c|c|c|}
\hline & All countries & France & Germany & Greece & Italy & Portugal & Spain & Sweden & Turkey & United Kingdom & United States \\
\hline Employment categories & $N=84,115$ & $N=5,010$ & $N=24,383$ & $N=4,000$ & $N=5,017$ & $N=4,003$ & $N=5,014$ & $N=4,010$ & $N=5,000$ & $N=23,643$ & $N=4,035$ \\
\hline \multirow[t]{2}{*}{ Employed full-time (1 = Yes) } & 0.334 & 0.341 & 0.314 & 0.249 & 0.248 & 0.380 & 0.336 & 0.505 & 0.246 & 0.356 & 0.405 \\
\hline & $(0.472)$ & $(0.474)$ & $(0.464)$ & $(0.433)$ & $(0.432)$ & $(0.485)$ & $(0.472)$ & $(0.500)$ & $(0.431)$ & $(0.479)$ & $(0.491)$ \\
\hline \multirow[t]{2}{*}{ Self-employed ( 1 = Yes) } & 0.058 & 0.040 & 0.054 & 0.129 & 0.082 & 0.060 & 0.042 & 0.031 & 0.087 & 0.055 & 0.042 \\
\hline & $(0.235)$ & $(0.195)$ & $(0.226)$ & $(0.335)$ & $(0.274)$ & $(0.237)$ & $(0.200)$ & $(0.174)$ & $(0.282)$ & $(0.227)$ & $(0.200)$ \\
\hline \multirow[t]{2}{*}{ Voluntarily part-time (1 = Yes) } & 0.084 & 0.046 & 0.106 & 0.028 & 0.088 & 0.027 & 0.045 & 0.061 & 0.050 & 0.107 & 0.076 \\
\hline & $(0.277)$ & $(0.208)$ & $(0.307)$ & $(0.165)$ & $(0.284)$ & $(0.163)$ & $(0.208)$ & $(0.240)$ & $(0.218)$ & $(0.309)$ & $(0.265)$ \\
\hline \multirow[t]{2}{*}{ Unemployed (1 = Yes) } & 0.044 & 0.045 & 0.027 & 0.080 & 0.048 & 0.048 & 0.122 & 0.036 & 0.049 & 0.036 & 0.053 \\
\hline & $(0.205)$ & $(0.208)$ & $(0.161)$ & $(0.271)$ & $(0.214)$ & $(0.214)$ & $(0.327)$ & $(0.185)$ & $(0.215)$ & $(0.187)$ & $(0.224)$ \\
\hline \multirow[t]{2}{*}{ Involuntarily part-time (1 = Yes) } & 0.040 & 0.035 & 0.035 & 0.041 & 0.052 & 0.025 & 0.065 & 0.034 & 0.026 & 0.039 & 0.069 \\
\hline & $(0.195)$ & $(0.184)$ & $(0.183)$ & $(0.199)$ & $(0.222)$ & $(0.157)$ & $(0.247)$ & $(0.181)$ & $(0.158)$ & $(0.192)$ & $(0.254)$ \\
\hline \multirow[t]{2}{*}{ Out of the labor force $(1=$ Yes $)$} & 0.440 & 0.493 & 0.465 & 0.473 & 0.482 & 0.460 & 0.390 & 0.332 & 0.543 & 0.407 & 0.354 \\
\hline & $(0.496)$ & $(0.500)$ & (0.499) & $(0.499)$ & $(0.500)$ & $(0.498)$ & $(0.488)$ & $(0.471)$ & $(0.498)$ & $(0.491)$ & (0.478) \\
\hline
\end{tabular}

Notes: Standard deviations in parentheses. Employment data are available starting in 2009. The table shows the proportion of respondents in each employment category. 
The "Out of the work force" category includes students, the disabled, homemakers, and retired individuals and GWP does not further disaggregate these groups. However, one GWP question furnishes some insights. In 2009 and 2010, respondents who were not employed were asked whether they were retired (Table 4). For the sample as a whole, about 60 percent of those who were not employed were retired. The percentage of the retired (of those who are not employed) was as high as 81 percent in Sweden and as low as 19 percent in Turkey.

\section{2) Employment status by age group}

Table 5 shows employment status by age group for the sample overall. As expected, full-time employment (for and employer and for self) is a concave function of age, peaking at ages 26-35 and 36-45 for those working for an employer and at ages 36-45 and 46-55 for the self-employed. Voluntary part-time employment is most common among the 36-45 and the 56-65-year-olds range, while involuntary part-time employment and unemployment are most common among the youngest respondents (age 25 and younger). Those in the 36-45 age group likely choose to work part-time because they may be raising children. In fact, 13.3 percent of respondents aged 36-45 with children in the household were voluntarily employed part-time compared with 5.4 percent of those in the same age group but without children (a statistically significant difference of 7.9 percentage points). Moreover, those in the 56-65 age group may be consciously choosing part-time work as a means to postponing retirement, especially in countries with relatively less generous pension systems.

Voluntary part-time work also varies by country ${ }^{12}$. Among all age groups, in Greece and its neighbor Turkey, voluntary part-time employment is most common in the 26-35 age group; in France, Germany, Italy, and Spain, voluntary part-time work is most widespread among the 36-45 age group; in Portugal and the UK - among the 56-65 age group; and in Sweden and the U.S. - among the 66-75 age group. Coincidentally,

Table 4 Retired status (Of those who are not employed), 2009-2010

\begin{tabular}{lcc}
\hline & \multicolumn{2}{c}{ Retired } \\
\cline { 2 - 3 } & Number & Percent \\
\hline All countries & 2,689 & 56.95 \\
France & 310 & 63.66 \\
Germany & 333 & 78.54 \\
Greece & 280 & 57.14 \\
Italy & 219 & 34.01 \\
Portugal & 299 & 70.35 \\
Spain & 172 & 35.83 \\
Sweden & 367 & 80.84 \\
Turkey & 85 & 19.45 \\
United Kingdom & 365 & 73.74 \\
United States & 259 & 67.10 \\
\hline
\end{tabular}

Source: Gallup World Poll, 2010-2011.

Notes: Standard deviations in parentheses. Only respondents who are not employed were asked this question. Data for France, Germany, Greece, Italy, Spain, Sweden, Turkey, the UK, and the US are for 2009; the data for Portugal are for 2010. 
Table 5 Employment status by age group, 2009-2012

\begin{tabular}{|c|c|c|c|c|c|c|c|c|}
\hline & All age groups & Age 25 and younger & $26-35$ years old & $36-45$ years old & $46-55$ years old & $56-65$ years old & $66-75$ years old & Age 76 and older \\
\hline Employment Categories & $N=84,115$ & $N=9,223$ & $N=10,316$ & $N=14,257$ & $N=15,464$ & $N=15,242$ & $N=11,849$ & $N=6,764$ \\
\hline \multirow[t]{2}{*}{ Employed full-time (1 = Yes) } & 0.334 & 0.249 & 0.542 & 0.539 & 0.517 & 0.267 & 0.019 & 0.004 \\
\hline & $(0.472)$ & $(0.432)$ & $(0.498)$ & $(0.498)$ & $(0.500)$ & $(0.443)$ & $(0.137)$ & $(0.062)$ \\
\hline \multirow[t]{2}{*}{ Self-employed ( 1 = Yes) } & 0.058 & 0.024 & 0.064 & 0.089 & 0.090 & 0.067 & 0.021 & 0.008 \\
\hline & $(0.235)$ & $(0.153)$ & $(0.245)$ & $(0.285)$ & $(0.287)$ & $(0.249)$ & $(0.145)$ & $(0.088)$ \\
\hline \multirow[t]{2}{*}{ Voluntarily employed part-time ( 1 = Yes) } & 0.084 & 0.081 & 0.076 & 0.103 & 0.089 & 0.107 & 0.064 & 0.023 \\
\hline & $(0.277)$ & $(0.272)$ & $(0.266)$ & $(0.303)$ & $(0.284)$ & $(0.309)$ & $(0.247)$ & $(0.149)$ \\
\hline \multirow[t]{2}{*}{ Unemployed ( 1 = Yes) } & 0.044 & 0.105 & 0.071 & 0.055 & 0.048 & 0.026 & 0.003 & 0.001 \\
\hline & $(0.205)$ & $(0.306)$ & $(0.256)$ & $(0.228)$ & $(0.214)$ & $(0.160)$ & $(0.057)$ & $(0.027)$ \\
\hline \multirow[t]{2}{*}{ Involuntarily employed part-time ( 1 = Yes) } & 0.040 & 0.079 & 0.057 & 0.052 & 0.046 & 0.026 & 0.009 & 0.003 \\
\hline & $(0.195)$ & $(0.269)$ & $(0.233)$ & $(0.221)$ & $(0.210)$ & $(0.160)$ & $(0.095)$ & $(0.058)$ \\
\hline \multirow[t]{2}{*}{ Out of the labor force $(1=$ Yes) } & 0.440 & 0.463 & 0.189 & 0.162 & 0.210 & 0.507 & 0.882 & 0.961 \\
\hline & $(0.496)$ & (0.499) & $(0.392)$ & $(0.369)$ & $(0.407)$ & $(0.500)$ & $(0.323)$ & $(0.193)$ \\
\hline
\end{tabular}

Notes: Standard deviations in parentheses. Employment data are available starting in 2009. For each age group, the table shows the proportion of respondents in each employment category. 
according to recent data, the U.S., UK, Sweden, and Portugal, are among the countries where older workers work the most (Thoma 2013).

\section{3) Employment status and well-being}

Table 6 reports the distribution of well-being and job satisfaction variables overall and by employment status ${ }^{13}$. First, voluntary part-timers had the greatest mean BPL score

Table 6 Well-being and job satisfaction by employment status, 2009-2012

\begin{tabular}{|c|c|c|c|c|c|c|}
\hline & BPL & $\begin{array}{l}\text { Happy } \\
\text { yesterday }\end{array}$ & $\begin{array}{c}\text { Stress } \\
\text { yesterday }\end{array}$ & $\begin{array}{c}\text { Anger } \\
\text { yesterday }\end{array}$ & $\begin{array}{c}\text { Job } \\
\text { satisfaction }\end{array}$ & Ideal job \\
\hline \multicolumn{7}{|c|}{ Variable Distribution Overall } \\
\hline Obs. & 86,673 & 85,265 & 85,619 & 85,630 & 37,612 & 37,300 \\
\hline Mean & 6.605 & 0.806 & 0.328 & 0.155 & 0.883 & 0.735 \\
\hline Std. Dev. & 1.976 & 0.395 & 0.470 & 0.362 & 0.321 & 0.442 \\
\hline \multicolumn{7}{|c|}{ Employment Categories } \\
\hline \multicolumn{7}{|c|}{ Employed Full-Time (1 = Yes) } \\
\hline Obs. & 28,044 & 27,904 & 27,987 & 27,984 & 24,656 & 23,788 \\
\hline Mean & 6.813 & 0.826 & 0.385 & 0.160 & 0.880 & 0.730 \\
\hline Std. Dev. & 1.709 & 0.380 & 0.487 & 0.367 & 0.325 & 0.444 \\
\hline \multicolumn{7}{|c|}{ Self-Employed (1 = Yes) } \\
\hline Obs. & 4,893 & 4,870 & 4,895 & 4,897 & 4,133 & 3,950 \\
\hline Mean & 6.684 & 0.806 & 0.403 & 0.163 & 0.897 & 0.825 \\
\hline Std. Dev. & 1.945 & 0.395 & 0.491 & 0.369 & 0.303 & 0.380 \\
\hline \multicolumn{7}{|c|}{$\begin{array}{l}\text { Voluntarily Employed Part-Time } \\
(1=\text { Yes })\end{array}$} \\
\hline Obs. & 7,003 & 6,993 & 7,003 & 7,004 & 6,194 & 5,903 \\
\hline Mean & 7.085 & 0.859 & 0.303 & 0.133 & 0.920 & 0.752 \\
\hline Std. Dev. & 1.762 & 0.348 & 0.460 & 0.340 & 0.271 & 0.432 \\
\hline \multicolumn{7}{|c|}{ Unemployed ( 1 = Yes) } \\
\hline Obs. & 3,688 & 3,666 & 3,678 & 3,683 & - & - \\
\hline Mean & 5.524 & 0.706 & 0.437 & 0.249 & - & - \\
\hline Std. Dev. & 2.307 & 0.456 & 0.496 & 0.432 & - & - \\
\hline \multicolumn{7}{|c|}{$\begin{array}{l}\text { Involuntarily Employed } \\
\text { Part-Time (1 = Yes) }\end{array}$} \\
\hline Obs. & 3,319 & 3,292 & 3,306 & 3,309 & 2,628 & 2,554 \\
\hline Mean & 6.296 & 0.807 & 0.408 & 0.202 & 0.801 & 0.605 \\
\hline Std. Dev. & 2.081 & 0.395 & 0.491 & 0.401 & 0.400 & 0.489 \\
\hline \multicolumn{7}{|c|}{ Out of the Labor Force ( $1=$ Yes $)$} \\
\hline Obs. & 36,652 & 36,539 & 36,738 & 36,740 & - & - \\
\hline Mean & 6.453 & 0.788 & 0.260 & 0.140 & - & - \\
\hline Std. Dev. & 2.102 & 0.409 & 0.439 & 0.347 & - & - \\
\hline
\end{tabular}

Source: Gallup World Poll, 2010-2013.

Notes: For each well-being variable, the top three rows show the tabulation of the variable for the sample as a whole, while the rest of the table shows tabulations by employment status. Best Possible Life (BPL) measures the respondent's assessment of her current life relative to her best possible life on a scale of 0 to 10 , where 0 is the worst possible life, and 10 is the best possible life. Experienced happiness yesterday, experienced stress yesterday, and experienced anger yesterday are binary variables coded as 1 if the respondent experienced this type of affect and 0 otherwise. Job satisfaction is a binary variable coded as 1 if the respondent responded that they are satisfied and 0 otherwise. Ideal Job is a binary variable coded as 1 if the respondent responded that their current job is ideal and 0 otherwise. Only respondents who are employed were asked about job satisfaction and ideal job. Employment data are available starting in 2009. Job satisfaction and ideal job data are available starting in 2010. 
(7.1 on a scale of 0 to 10 ), while the unemployed had the lowest score $(5.5)^{14}$. Second, in all countries in the sample, the voluntarily employed part-time workers were the happiest group, followed by the full-time workers, while the unemployed had the lowest share of respondents who experienced happiness the day before ${ }^{15}$. Third, about a third of all respondents in the sample experienced stress the day before, with the highest proportion being in Greece (53 percent) and Turkey (49 percent), and the lowest in Germany (27 percent), Sweden (28 percent), and the UK (29 percent) (not shown). Those who are out of the workforce were the least stressed group (26 percent), followed by the voluntarily employed part-time (30 percent); while the most stressed were the unemployed (44 percent) ${ }^{16}$. Fourth, nearly 16 percent of respondents reported being angry the previous day, ranging from as many as 36 percent in Turkey to as low as 9 percent in Portugal. The unemployed reported the highest rates of anger, while the voluntary part-time employees had the lowest.

Starting in 2010, those who are employed were asked whether: (i) they were satisfied with their jobs; and (ii) their job was the ideal one for them. Overall, about 88 percent of respondents who were employed reported that they were satisfied with their jobs ${ }^{17}$. Voluntary part-time workers had the highest job satisfaction rates (92 percent), compared with 80 percent of the involuntarily employed part-time. Almost three out of four workers (74 percent) reported that their current job was the ideal one for them and among the employment categories, the self-employed were most likely to report that their job was ideal (83 percent), while the involuntarily part-time workers were least likely to report so $(61 \text { percent })^{18}$.

\section{Regression results}

\section{1) Best possible life and positive hedonic well-being}

As noted above, the BPL equations are estimated using ordered logits and all others are estimated using logits ${ }^{19}$.

All regressions include the standard socio-demographic controls, country dummies, and where appropriate, year dummies.

Based on the results from Model (1) in Table 7, the voluntarily employed part-time and the self-employed have higher evaluative SWB (relative to those who are employed full-time for an employer), controlling for the other variables in the model. Being unemployed and involuntarily employed part-time have a negative association with BPL, while being out of the labor force is not statistically significant.

Model (2) adds interaction terms for age and employment to test whether the relationship between the employment variables and BPL varies by age. We find an additional positive effect of being employed full-time and voluntarily employed part-time for older cohorts (those in the 46-65 age group and those aged 66 and older). Being self-employed has an additional positive effect on happiness (i.e., BPL) only for the oldest cohort - i.e., those aged 66 and older. There is an additional negative influence on BPL from being unemployed for the 46-65 age group but not for the 66 and older age group.

Being self-employed is positively correlated with hedonic happiness while being unemployed is negatively correlated with it (relative to full-time employees) (Model (3)). The coefficient estimates for the voluntary and for the involuntary part-time workers 
Table 7 Evaluative and hedonic well-being regressions, 2009-2012

\begin{tabular}{|c|c|c|c|c|}
\hline Variables & $\begin{array}{c}(1) \\
\text { BPL }\end{array}$ & $\begin{array}{r}(2) \\
\text { BPL }\end{array}$ & $\begin{array}{c}\text { (3) } \\
\text { Happy }\end{array}$ & $\begin{array}{c}\text { (4) } \\
\text { Happy }\end{array}$ \\
\hline \multicolumn{5}{|c|}{ Employment categories (Ref. Group: employed full-time) } \\
\hline \multirow[t]{2}{*}{ Self-employed (1 = Yes) } & $0.114^{* *}$ & $0.135^{* *}$ & $0.219^{* * *}$ & $0.215^{* *}$ \\
\hline & $(0.046)$ & $(0.061)$ & $(0.066)$ & $(0.090)$ \\
\hline \multirow[t]{2}{*}{ Voluntarily employed part-time ( 1 = Yes) } & $0.270^{* * *}$ & $0.182^{* * *}$ & $0.199^{* * *}$ & 0.046 \\
\hline & $(0.046)$ & $(0.063)$ & $(0.072)$ & $(0.105)$ \\
\hline \multirow[t]{2}{*}{ Unemployed ( 1 = Yes) } & $-0.854^{* * *}$ & $-0.725^{* * *}$ & $-0.387^{* * *}$ & $-0.412^{* * *}$ \\
\hline & $(0.056)$ & $(0.067)$ & $(0.068)$ & $(0.085)$ \\
\hline \multirow[t]{2}{*}{ Involuntarily employed part-time (1 = Yes) } & $-0.383^{* * *}$ & $-0.286^{* * *}$ & -0.111 & $-0.193^{* *}$ \\
\hline & -0.055 & $(0.066)$ & $(0.077)$ & $(0.098)$ \\
\hline \multirow[t]{2}{*}{ Out of the labor force $(1=$ Yes $)$} & -0.047 & 0.007 & $0.077^{*}$ & 0.038 \\
\hline & $(0.030)$ & $(0.041)$ & $(0.042)$ & $(0.061)$ \\
\hline \multirow[t]{2}{*}{ Age } & $-0.063^{* * *}$ & $-0.064^{* * *}$ & $-0.058^{* * *}$ & $-0.056^{* * *}$ \\
\hline & $(0.004)$ & $(0.005)$ & $(0.005)$ & $(0.007)$ \\
\hline \multirow[t]{2}{*}{ Age squared } & $0.001^{* * *}$ & $0.001^{* * *}$ & $0.000^{* * *}$ & $0.000^{* * *}$ \\
\hline & $(0.000)$ & $(0.000)$ & $(0.000)$ & $(0.000)$ \\
\hline \multicolumn{5}{|l|}{ Employment and age Interactions } \\
\hline \multirow[t]{2}{*}{ Employed full-time*Age 46 to 65} & & $0.167^{* * *}$ & & $0.158^{* *}$ \\
\hline & & $(0.045)$ & & $(0.070)$ \\
\hline \multirow[t]{2}{*}{ Employed full-time*Age 66 and older } & & $0.453^{* *}$ & & $0.891^{* *}$ \\
\hline & & $(0.211)$ & & $(0.351)$ \\
\hline \multirow[t]{2}{*}{ Self employed*Age 46 to 65} & & 0.062 & & $0.231^{*}$ \\
\hline & & $(0.092)$ & & $(0.131)$ \\
\hline \multirow[t]{2}{*}{ Self employed* Age 66 and older } & & $0.677^{* * *}$ & & 0.135 \\
\hline & & $(0.237)$ & & $(0.302)$ \\
\hline \multirow[t]{2}{*}{ Voluntary part-time*Age 46 to 65} & & $0.298^{* * *}$ & & $0.319^{* *}$ \\
\hline & & $(0.097)$ & & $(0.150)$ \\
\hline \multirow[t]{2}{*}{ Voluntary part-time*Age 66 and older } & & $0.444^{* * *}$ & & $1.250^{* * *}$ \\
\hline & & $(0.158)$ & & $(0.259)$ \\
\hline \multirow[t]{2}{*}{ Unemployed*Age 46 to 65} & & $-0.240^{* *}$ & & 0.181 \\
\hline & & $(0.115)$ & & $(0.139)$ \\
\hline \multirow[t]{2}{*}{ Unemployed*Age 66 and older } & & 0.550 & & $1.998^{* *}$ \\
\hline & & $(0.961)$ & & $(0.907)$ \\
\hline \multirow[t]{2}{*}{ Involuntary part-time*Age 46 to 65} & & -0.138 & & $0.357^{* *}$ \\
\hline & & $(0.122)$ & & $(0.159)$ \\
\hline \multirow[t]{2}{*}{ Involuntary part-time*Age 66 and older } & & 0.279 & & 0.752 \\
\hline & & $(0.284)$ & & $(0.495)$ \\
\hline \multirow[t]{2}{*}{ Out of the labor force*Age 46 to 65} & & 0.067 & & $0.227^{* *}$ \\
\hline & & $(0.066)$ & & $(0.091)$ \\
\hline \multirow[t]{2}{*}{ Out of the labor force*Age 66 and older } & & 0.111 & & $0.529^{* * *}$ \\
\hline & & $(0.094)$ & & $(0.124)$ \\
\hline
\end{tabular}


Table 7 Evaluative and hedonic well-being regressions, 2009-2012 (Continued)

\begin{tabular}{|c|c|c|c|c|}
\hline \multirow[t]{2}{*}{ Female (1=Yes) } & $0.114^{* * *}$ & $0.113^{* * *}$ & 0.012 & 0.018 \\
\hline & $(0.022)$ & $(0.022)$ & $(0.031)$ & $(0.031)$ \\
\hline \multirow[t]{2}{*}{ Married (1=Yes) } & $0.248^{* * *}$ & $0.251^{* * *}$ & $0.407^{* * *}$ & $0.411^{* * *}$ \\
\hline & $(0.026)$ & $(0.026)$ & $(0.035)$ & $(0.035)$ \\
\hline \multirow[t]{2}{*}{ Some college or college diploma ( $1=$ Yes) } & $0.393^{* * *}$ & $0.396^{* * *}$ & 0.039 & 0.040 \\
\hline & $(0.026)$ & $(0.026)$ & $(0.040)$ & $(0.040)$ \\
\hline \multirow[t]{2}{*}{ Log household income (in ID) } & $0.374^{* * *}$ & $0.372^{* * *}$ & $0.203^{* * *}$ & $0.203^{* * *}$ \\
\hline & $(0.021)$ & $(0.021)$ & $(0.017)$ & $(0.017)$ \\
\hline \multirow[t]{2}{*}{ Urban area (1=Yes) } & $-0.046^{* *}$ & $-0.045^{* *}$ & -0.001 & 0.001 \\
\hline & $(0.022)$ & $(0.022)$ & $(0.031)$ & $(0.031)$ \\
\hline \multirow[t]{2}{*}{ Child in household (1=Yes) } & $-0.106^{* * *}$ & $-0.085^{* * *}$ & 0.056 & $0.080^{* *}$ \\
\hline & $(0.026)$ & $(0.027)$ & $(0.038)$ & $(0.040)$ \\
\hline \multirow[t]{2}{*}{ Household size } & $-0.031^{* * *}$ & $-0.034^{* * *}$ & -0.014 & -0.015 \\
\hline & $(0.007)$ & $(0.007)$ & $(0.014)$ & $(0.013)$ \\
\hline \multirow[t]{2}{*}{ Religion important ( $1=$ Yes) } & 0.010 & 0.010 & $0.184^{* * *}$ & $0.183^{* * *}$ \\
\hline & $(0.025)$ & $(0.025)$ & $(0.035)$ & $(0.035)$ \\
\hline \multicolumn{5}{|l|}{ Country Dummies (Ref. Group: United States) } \\
\hline \multirow[t]{2}{*}{ Turkey } & $-1.333^{* * *}$ & $-1.330^{* * *}$ & $-1.319^{* * *}$ & $-1.313^{* * *}$ \\
\hline & $(0.064)$ & $(0.064)$ & $(0.088)$ & $(0.088)$ \\
\hline \multirow[t]{2}{*}{ UK } & $-0.249 * * *$ & $-0.242^{* * *}$ & 0.018 & 0.026 \\
\hline & $(0.062)$ & $(0.063)$ & $(0.105)$ & $(0.105)$ \\
\hline \multirow[t]{2}{*}{ France } & $-0.573^{* * *}$ & $-0.566^{* * *}$ & $-1.019^{* * *}$ & $-1.007^{* * *}$ \\
\hline & $(0.055)$ & $(0.055)$ & $(0.084)$ & $(0.084)$ \\
\hline \multirow[t]{2}{*}{ Germany } & $-0.614^{* * *}$ & $-0.605^{* * *}$ & $-0.171^{* *}$ & $-0.165^{*}$ \\
\hline & $(0.052)$ & $(0.052)$ & $(0.086)$ & $(0.086)$ \\
\hline \multirow[t]{2}{*}{ Spain } & $-0.596^{* * *}$ & $-0.586^{* * *}$ & $-0.607^{* * *}$ & $-0.595^{* * *}$ \\
\hline & $(0.056)$ & $(0.056)$ & $(0.087)$ & $(0.087)$ \\
\hline \multirow[t]{2}{*}{ Italy } & $-0.748^{* * *}$ & $-0.740^{* * *}$ & $-1.721^{* * *}$ & $-1.703^{* * *}$ \\
\hline & $(0.064)$ & $(0.064)$ & $(0.092)$ & $(0.092)$ \\
\hline \multirow[t]{2}{*}{ Sweden } & 0.008 & 0.012 & $-0.986^{* * *}$ & $-0.978^{* * *}$ \\
\hline & $(0.053)$ & $(0.053)$ & $(0.084)$ & $(0.084)$ \\
\hline \multirow[t]{2}{*}{ Greece } & $-1.252^{* * *}$ & $-1.235^{* * *}$ & $-2.212^{* * *}$ & $-2.202^{* * *}$ \\
\hline & $(0.059)$ & $(0.060)$ & $(0.081)$ & $(0.082)$ \\
\hline \multirow[t]{2}{*}{ Portugal } & $-1.794^{* * *}$ & $-1.786^{* * *}$ & $-0.871^{* * *}$ & $-0.866^{* * *}$ \\
\hline & $(0.061)$ & $(0.061)$ & $(0.090)$ & $(0.090)$ \\
\hline Year Dummies & Yes & Yes & Yes & Yes \\
\hline Observations & 27,779 & 27,779 & 27,492 & 27,492 \\
\hline Pseudo R2 & 0.056 & 0.057 & 0.0961 & 0.0974 \\
\hline
\end{tabular}

Source: Gallup World Poll, 2010-2013.

Notes: All regressions are for 2009-2012 and use country and year dummies and report robust standard errors (in parentheses). The dependent variable in models (1) and (2) is BPL which measures the respondent's assessment of her current life relative to her best possible life on a scale of 0 to 10 , where 0 is the worst possible life, and 10 is the best possible life. The dependent variable in models (3) and (4) is whether or not the respondent experienced happiness yesterday. Models (1) and (2) are estimated using ordered logits, models (3) and (4) are estimated using logits. Household income is log-transformed and is in international dollars (ID), which allows comparisons across countries and time.

${ }^{* * *} p<0.01,{ }^{* *} p<0.05,{ }^{*} p<0.1$. 
and out of the workforce change significance when we add the interaction terms in Model (4). Being voluntarily employed part-time is no longer positive and significant once the interaction terms are included but there is a happiness "premium" for voluntary workers aged 46 and older (relative to the young). The self-employed aged between 46 and 65 are marginally happier than the young. Oddly, those who are in the 66 and older age group and are unemployed as well as the involuntary part-time workers aged 46 to 65 are in fact happier than the young.

These results imply that that there are additional happiness benefits of (voluntary) full-time and part-time work (including self-employment) and based on the magnitude of the unstandardized coefficients in Models (2) and (4), it appears that these benefits are greatest for those in the oldest cohort (age 66 and older).

\section{2) Job satisfaction}

Table 8 demonstrates how various employment variables relate to job satisfaction ${ }^{20}$. Relative to those employed full-time, the self-employed and voluntarily employed part-time were marginally more satisfied with their jobs (Model (1)), while those who are involuntarily employed part-time were less satisfied with their jobs. The coefficient estimate for voluntary part-time employment becomes statistically insignificant when the age and employment interactions are included in Model (2). There are no additional well-being effects for older respondents across the employment categories as compared with the young workers.

The self-employed were more likely to report that their job was the ideal one for them (compared with full-time workers) while those who were involuntarily employed full-time were less likely to report so (Model (3)). The voluntary part-time workers were as likely as their full-time counterparts to think their job is ideal. The interaction terms show that, compared with the young, older workers (i.e., those aged 66 and older) who were employed full-time and voluntarily employed part-time were more likely to report that their job was ideal (Model (4)).

The ideal job variable may be an evaluative measure of job satisfaction, i.e., one that encompasses meaningful work and creativity at work, rather than the day-to-day satisfaction/dissatisfaction with the work one does. Therefore, this dimension may in part be reflective of older worker's control over their work.

\section{3) Negative hedonic affect}

Along with experiencing anger, experiencing stress yesterday is a negative hedonic SWB indicator. The results in Table 9 show that the voluntary part-timers and those out of the workforce experience less stress compared with the full-time workers. Compared with the younger respondents (i.e., those aged 45 and younger), full-time workers aged 66 and older, the voluntary part-timers aged 46 and older, the involuntary part-timers aged 46-65, and those out of the workforce aged 46 and older experienced less stress, on average.

Table 9 also shows that the unemployed were more likely to report experiencing anger compared with the full-time workers. In contrast, those who were out of the labor force reported less anger than full-time workers. Based on Model (4), which adds the age and employment interactions, being self-employed is negatively associated with anger, compared with full-time status. Most of the interaction terms are either nonsignificant or marginally significant, meanwhile. On balance, they suggest less stress 
Table 8 Job satisfaction regressions, 2010-2012

\begin{tabular}{|c|c|c|c|c|}
\hline Variables & $\begin{array}{c}\text { (1) } \\
\text { Job satisfaction }\end{array}$ & $\begin{array}{c}(2) \\
\text { Job satisfaction }\end{array}$ & $\begin{array}{c}\text { (3) } \\
\text { Ideal job }\end{array}$ & $\begin{array}{c}\text { (4) } \\
\text { Ideal job }\end{array}$ \\
\hline \multicolumn{5}{|c|}{ Employment Categories (Ref. Group: Employed Full-time) } \\
\hline \multirow[t]{2}{*}{ Self-Employed ( 1 = Yes) } & $0.176^{*}$ & $0.237^{*}$ & $0.501^{* * *}$ & $0.553^{* * *}$ \\
\hline & $(0.095)$ & $(0.129)$ & $(0.080)$ & $(0.106)$ \\
\hline \multirow[t]{2}{*}{ Voluntarily employed part-time ( 1 = Yes) } & $0.188^{*}$ & 0.125 & 0.081 & -0.081 \\
\hline & $(0.110)$ & $(0.147)$ & $(0.078)$ & $(0.101)$ \\
\hline \multirow[t]{2}{*}{ Involuntarily employed part-time ( $1=$ Yes $)$} & $-0.581^{* * *}$ & $-0.649^{* * *}$ & $-0.417^{* * *}$ & $-0.351^{* * *}$ \\
\hline & $(0.098)$ & $(0.123)$ & $(0.080)$ & $(0.100)$ \\
\hline \multirow[t]{2}{*}{ Age } & $-0.054^{* * *}$ & $-0.047^{* *}$ & 0.002 & $0.023^{*}$ \\
\hline & $(0.016)$ & $(0.019)$ & $(0.011)$ & $(0.013)$ \\
\hline \multirow[t]{2}{*}{ Age Squared } & $0.001^{* * *}$ & $0.001^{* *}$ & 0.000 & -0.000 \\
\hline & $(0.000)$ & $(0.000)$ & $(0.000)$ & $(0.000)$ \\
\hline \multicolumn{5}{|l|}{ Employment and Age Interactions } \\
\hline \multirow[t]{2}{*}{ Employed full-time*Age 46 to 65} & & -0.181 & & -0.068 \\
\hline & & $(0.121)$ & & $(0.091)$ \\
\hline \multirow[t]{2}{*}{ Employed full-time*Age 66 and older } & & 0.210 & & $1.469^{* *}$ \\
\hline & & $(0.611)$ & & $(0.609)$ \\
\hline \multirow[t]{2}{*}{ Self employed*Age 46 to 65} & & -0.327 & & -0.164 \\
\hline & & $(0.201)$ & & $(0.172)$ \\
\hline \multirow[t]{2}{*}{ Self employed*Age 66 and older } & & -0.025 & & 0.054 \\
\hline & & $(0.604)$ & & $(0.463)$ \\
\hline \multirow[t]{2}{*}{ Voluntary part-time ${ }^{*}$ Age 46 to 65} & & -0.080 & & 0.282 \\
\hline & & $(0.237)$ & & $(0.175)$ \\
\hline \multirow[t]{2}{*}{ Voluntary part-time*Age 66 and older } & & 0.153 & & $0.770^{* *}$ \\
\hline & & $(0.459)$ & & $(0.355)$ \\
\hline \multirow[t]{2}{*}{ Involuntary part-time*Age 46 to 65} & & 0.031 & & -0.240 \\
\hline & & $(0.206)$ & & $(0.169)$ \\
\hline \multirow[t]{2}{*}{ Involuntary part-time*Age 66 and older } & & -0.239 & & 0.607 \\
\hline & & $(0.634)$ & & $(0.600)$ \\
\hline \multirow[t]{2}{*}{ Female ( 1 = Yes) } & 0.042 & 0.043 & 0.040 & 0.045 \\
\hline & $(0.062)$ & $(0.062)$ & $(0.046)$ & $(0.046)$ \\
\hline \multirow[t]{2}{*}{ Married ( 1 = Yes) } & $0.248 * * *$ & $0.244^{* * *}$ & $0.162^{* * *}$ & $0.159^{* * *}$ \\
\hline & $(0.073)$ & $(0.073)$ & $(0.054)$ & $(0.055)$ \\
\hline \multirow[t]{2}{*}{ Some college or college diploma ( 1 = Yes) } & $0.132^{*}$ & $0.125^{*}$ & $0.140^{* * *}$ & $0.136^{* *}$ \\
\hline & $(0.074)$ & $(0.074)$ & $(0.053)$ & $(0.053)$ \\
\hline \multirow[t]{2}{*}{ Log husehold income (in ID) } & $0.334^{* * *}$ & $0.334^{* * *}$ & $0.276^{* * *}$ & $0.278^{* * *}$ \\
\hline & $(0.049)$ & $(0.049)$ & $(0.043)$ & $(0.043)$ \\
\hline \multirow[t]{2}{*}{ Urban area $(1=$ Yes $)$} & -0.020 & -0.019 & $-0.132^{* * *}$ & $-0.132^{* * *}$ \\
\hline & $(0.063)$ & $(0.063)$ & $(0.046)$ & $(0.046)$ \\
\hline \multirow[t]{2}{*}{ Child in household ( $1=$ Yes) } & -0.051 & -0.079 & 0.021 & -0.006 \\
\hline & $(0.069)$ & $(0.071)$ & $(0.052)$ & $(0.054)$ \\
\hline \multirow[t]{2}{*}{ Household size } & $-0.070^{* * *}$ & $-0.060^{* *}$ & $-0.049^{* *}$ & $-0.039^{*}$ \\
\hline & $(0.027)$ & $(0.027)$ & $(0.021)$ & $(0.021)$ \\
\hline
\end{tabular}


Table 8 Job satisfaction regressions, 2010-2012 (Continued)

\begin{tabular}{|c|c|c|c|c|}
\hline \multirow[t]{2}{*}{ Religion important $(1=$ Yes $)$} & 0.110 & 0.110 & $0.138^{* * *}$ & $0.140^{* * *}$ \\
\hline & $(0.069)$ & $(0.069)$ & $(0.051)$ & $(0.051)$ \\
\hline \multicolumn{5}{|c|}{ Country Dummies (Ref. Group: United States } \\
\hline \multirow[t]{2}{*}{ Turkey } & $-0.483^{* *}$ & $-0.499^{* * *}$ & $0.270^{* *}$ & $0.278^{* *}$ \\
\hline & (0.190) & $(0.191)$ & $(0.117)$ & $(0.117)$ \\
\hline \multirow[t]{2}{*}{ UK } & -0.144 & -0.138 & 0.106 & 0.118 \\
\hline & $(0.211)$ & $(0.211)$ & $(0.145)$ & $(0.146)$ \\
\hline \multirow[t]{2}{*}{ France } & -0.277 & -0.271 & -0.133 & -0.117 \\
\hline & $(0.186)$ & $(0.186)$ & $(0.107)$ & $(0.107)$ \\
\hline \multirow[t]{2}{*}{ Germany } & 0.240 & 0.241 & $0.323^{* * *}$ & $0.341^{* * *}$ \\
\hline & $(0.181)$ & $(0.181)$ & $(0.100)$ & $(0.100)$ \\
\hline \multirow[t]{2}{*}{ Spain } & 0.121 & 0.115 & -0.127 & -0.119 \\
\hline & (0.188) & $(0.188)$ & $(0.104)$ & $(0.105)$ \\
\hline \multirow[t]{2}{*}{ Italy } & -0.132 & -0.133 & 0.002 & 0.013 \\
\hline & (0.209) & $(0.210)$ & (0.130) & $(0.131)$ \\
\hline \multirow[t]{2}{*}{ Sweden } & $0.342^{*}$ & $0.343^{*}$ & $0.293^{* * *}$ & $0.308^{* * *}$ \\
\hline & $(0.187)$ & $(0.187)$ & $(0.100)$ & $(0.101)$ \\
\hline \multirow[t]{2}{*}{ Greece } & $-0.626^{* * *}$ & $-0.637^{* * *}$ & $-0.229^{* *}$ & $-0.226^{* *}$ \\
\hline & (0.183) & $(0.184)$ & $(0.111)$ & $(0.111)$ \\
\hline \multirow[t]{2}{*}{ Portugal } & -0.113 & -0.122 & $0.506^{* * *}$ & $0.505^{* * *}$ \\
\hline & (0.195) & $(0.195)$ & $(0.121)$ & $(0.122)$ \\
\hline Year Dummies & Yes & Yes & Yes & Yes \\
\hline Observations & 10,526 & 10,526 & 10,762 & 10,762 \\
\hline Pseudo R2 & 0.0548 & 0.0556 & 0.0464 & 0.0482 \\
\hline
\end{tabular}

Source: Gallup World Poll, 2011-2013.

Notes: All logistic regressions are for 2010-2012 and use country and year dummies and report robust standard errors (in parentheses). Job satisfaction and ideal job are available starting in 2010. The dependent variable in Models (1) and (2) is job satisfaction (coded as 1 if the respondent is satisfied and 0 otherwise). The dependent variable Models (3) and (4) is ideal job (coded as 1 if the respondent thought that her current job was the ideal one for her and 0 otherwise). Household income is log-transformed and is in international dollars (ID), which allows comparisons across countries and time. *** $p<0.01,{ }^{* *} p<0.05,{ }^{*} p<0.1$.

and anger among older cohorts, which is in keeping with other research showing smaller standard deviations in emotions as people age (Carstensen et al. 2011).

\section{Propensity score matching results}

We explored the well-being effect of retiring compared to late-life work by calculating the Average Treatment Effect on the Treated (ATT) using PSM. The treatment variable in all models is "Retired." The goal of the matching procedure is to find a group of non-retirees who are similar to retirees along observable characteristics except that they are still working for pay (either part-time or full-time). We used one-to-one nearest neighbor matching with a caliper (maximum allowable distance between the propensity scores) of 0.001 , which is relatively conservative ${ }^{21}$. Table 10 presents the PSM results using four control groups: the voluntarily employed part-time workers, the fulltime employees, the self-employed, and the involuntarily employed part-time. All results are for 2009-2010 due to the availability of the retirement variable. 
Table 9 Experienced stress and anger yesterday regressions, 2009-2012

\begin{tabular}{|c|c|c|c|c|}
\hline Variables & $\begin{array}{c}(1) \\
\text { Stress }\end{array}$ & $\begin{array}{c}(2) \\
\text { Stress }\end{array}$ & $\begin{array}{c}(3) \\
\text { Anger }\end{array}$ & $\begin{array}{c}(4) \\
\text { Anger } \\
\end{array}$ \\
\hline \multicolumn{5}{|c|}{ Employment categories (Ref. Group: employed full-time) } \\
\hline \multirow[t]{2}{*}{ Self-employed (1 = Yes) } & 0.010 & 0.017 & -0.016 & $-0.176^{* *}$ \\
\hline & $(0.056)$ & $(0.075)$ & $(0.068)$ & $(0.087)$ \\
\hline \multirow[t]{2}{*}{ Voluntarily employed part-time (1 = Yes) } & $-0.350^{* * *}$ & $-0.159^{*}$ & $-0.126^{*}$ & -0.075 \\
\hline & $(0.058)$ & $(0.081)$ & $(0.072)$ & $(0.094)$ \\
\hline \multirow[t]{2}{*}{ Unemployed ( 1 = Yes) } & 0.091 & 0.067 & $0.312^{* * *}$ & $0.210^{* * *}$ \\
\hline & $(0.059)$ & $(0.072)$ & $(0.066)$ & $(0.079)$ \\
\hline \multirow[t]{2}{*}{ Involuntarily Employed Part-Time (1 = Yes) } & 0.012 & 0.105 & $0.199^{* * *}$ & 0.101 \\
\hline & $(0.062)$ & $(0.077)$ & $(0.072)$ & $(0.088)$ \\
\hline \multirow[t]{2}{*}{ Out of the labor force $(1=$ Yes $)$} & $-0.391^{* * *}$ & $-0.336^{* * *}$ & $-0.093^{* *}$ & $-0.104^{*}$ \\
\hline & $(0.037)$ & $(0.050)$ & $(0.044)$ & $(0.056)$ \\
\hline \multirow[t]{2}{*}{ Age } & $0.023^{* * *}$ & $0.023^{* * *}$ & $0.032^{* * *}$ & $0.036^{* * *}$ \\
\hline & $(0.005)$ & $(0.006)$ & $(0.006)$ & $(0.007)$ \\
\hline \multirow[t]{2}{*}{ Age squared } & $-0.000^{* * *}$ & $-0.000^{* * *}$ & $-0.000^{* * *}$ & $-0.000^{* * *}$ \\
\hline & $(0.000)$ & $(0.000)$ & $(0.000)$ & $(0.000)$ \\
\hline \multicolumn{5}{|l|}{ Employment and Age Interactions } \\
\hline \multirow[t]{2}{*}{ Employed full-time*Age 46 to 65} & & -0.069 & & $-0.233^{* * *}$ \\
\hline & & $(0.059)$ & & $(0.071)$ \\
\hline \multirow[t]{2}{*}{ Employed full-time*Age 66 and older } & & $-0.802^{* * *}$ & & 0.123 \\
\hline & & $(0.296)$ & & $(0.340)$ \\
\hline \multirow[t]{2}{*}{ Self employed*Age 46 to 65} & & -0.143 & & 0.138 \\
\hline & & $(0.112)$ & & $(0.135)$ \\
\hline \multirow[t]{2}{*}{ Self employed* Age 66 and older } & & 0.051 & & $0.552^{*}$ \\
\hline & & $(0.258)$ & & $(0.327)$ \\
\hline \multirow[t]{2}{*}{ Voluntary part-time*Age 46 to 65} & & $-0.389^{* * *}$ & & $-0.279^{*}$ \\
\hline & & $(0.124)$ & & $(0.153)$ \\
\hline \multirow[t]{2}{*}{ Voluntary part-time*Age 66 and older } & & $-1.072^{* * *}$ & & $-0.537^{*}$ \\
\hline & & $(0.237)$ & & $(0.300)$ \\
\hline \multirow[t]{2}{*}{ Unemployed*Age 46 to 65} & & 0.027 & & 0.120 \\
\hline & & $(0.121)$ & & $(0.138)$ \\
\hline \multirow[t]{2}{*}{ Unemployed*Age 66 and older } & & -0.305 & & -0.052 \\
\hline & & $(0.624)$ & & $(0.867)$ \\
\hline \multirow[t]{2}{*}{ Involuntary part-time*Age 46 to 65} & & $-0.330^{* *}$ & & 0.135 \\
\hline & & $(0.131)$ & & $(0.150)$ \\
\hline \multirow[t]{2}{*}{ Involuntary part-time*Age 66 and older } & & -0.497 & & $-1.234^{*}$ \\
\hline & & $(0.406)$ & & $(0.715)$ \\
\hline \multirow[t]{2}{*}{ Out of the labor force*Age 46 to 65} & & $-0.206^{* * *}$ & & $-0.162^{*}$ \\
\hline & & $(0.077)$ & & $(0.090)$ \\
\hline \multirow[t]{2}{*}{ Out of the labor force*Age 66 and older } & & $-0.330^{* * *}$ & & -0.210 \\
\hline & & $(0.113)$ & & $(0.141)$ \\
\hline
\end{tabular}


Table 9 Experienced stress and anger yesterday regressions, 2009-2012 (Continued)

\begin{tabular}{|c|c|c|c|c|}
\hline \multirow[t]{2}{*}{$\overline{\text { Female }(1=\text { Yes })}$} & $0.328^{* * *}$ & $0.325^{* * *}$ & $0.111^{* * *}$ & $0.108^{* * *}$ \\
\hline & $(0.027)$ & $(0.027)$ & $(0.032)$ & $(0.033)$ \\
\hline \multirow[t]{2}{*}{ Married (1 = Yes) } & -0.015 & -0.018 & $-0.101^{* * *}$ & $-0.109^{* * *}$ \\
\hline & $(0.031)$ & $(0.032)$ & $(0.037)$ & $(0.037)$ \\
\hline \multirow[t]{2}{*}{ Some college or college diploma ( 1 = Yes) } & 0.006 & 0.004 & -0.046 & -0.053 \\
\hline & $(0.033)$ & $(0.033)$ & $(0.041)$ & $(0.041)$ \\
\hline \multirow[t]{2}{*}{ Log household income (in ID) } & $-0.092^{* * *}$ & $-0.092^{* * *}$ & $-0.128^{* * *}$ & $-0.126^{* * *}$ \\
\hline & $(0.015)$ & $(0.015)$ & $(0.015)$ & $(0.015)$ \\
\hline \multirow[t]{2}{*}{ Urban area (1 = Yes) } & $0.094^{* * *}$ & $0.094^{* * *}$ & $0.165^{* * *}$ & $0.165^{* * *}$ \\
\hline & $(0.027)$ & $(0.027)$ & $(0.032)$ & $(0.032)$ \\
\hline \multirow[t]{2}{*}{ Child in household ( 1 = Yes) } & $0.157^{* * *}$ & $0.135^{* * *}$ & $0.262^{* * *}$ & $0.239^{* * *}$ \\
\hline & $(0.032)$ & $(0.033)$ & $(0.037)$ & $(0.039)$ \\
\hline \multirow[t]{2}{*}{ Household size } & $0.031^{* *}$ & $0.032^{* *}$ & $0.043^{* * *}$ & $0.047^{* * *}$ \\
\hline & $(0.014)$ & $(0.015)$ & $(0.011)$ & $(0.011)$ \\
\hline \multirow[t]{2}{*}{ Religion important ( 1 = Yes) } & $0.053^{*}$ & $0.053^{*}$ & -0.023 & -0.023 \\
\hline & $(0.030)$ & $(0.030)$ & $(0.036)$ & $(0.036)$ \\
\hline \multicolumn{5}{|l|}{ Country Dummies (Ref. Group: United States) } \\
\hline \multirow[t]{2}{*}{ Turkey } & $-0.260^{* * *}$ & $-0.270^{* * *}$ & $0.684^{* * *}$ & $0.683^{* * *}$ \\
\hline & $(0.064)$ & $(0.064)$ & $(0.075)$ & $(0.075)$ \\
\hline \multirow[t]{2}{*}{ UK } & $-0.500^{* * *}$ & $-0.515^{* * *}$ & $-0.269^{* * *}$ & $-0.273^{* * *}$ \\
\hline & $(0.070)$ & $(0.070)$ & $(0.092)$ & $(0.092)$ \\
\hline \multirow[t]{2}{*}{ France } & $-0.397^{* * *}$ & $-0.409^{* * *}$ & $0.707^{* * *}$ & $0.710^{* * *}$ \\
\hline & $(0.061)$ & $(0.061)$ & $(0.072)$ & $(0.073)$ \\
\hline \multirow[t]{2}{*}{ Germany } & $-0.629^{* * *}$ & $-0.642^{* * *}$ & $-0.285^{* * *}$ & $-0.288^{* * *}$ \\
\hline & $(0.058)$ & (0.059) & $(0.077)$ & $(0.077)$ \\
\hline \multirow[t]{2}{*}{ Spain } & $-0.732^{* * *}$ & $-0.746^{* * *}$ & $0.240^{* * *}$ & $0.236^{* * *}$ \\
\hline & $(0.061)$ & $(0.062)$ & $(0.073)$ & $(0.074)$ \\
\hline \multirow[t]{2}{*}{ Italy } & $-0.256^{* * *}$ & $-0.273^{* * *}$ & $-0.201^{* *}$ & $-0.203^{* *}$ \\
\hline & $(0.073)$ & $(0.074)$ & $(0.096)$ & $(0.097)$ \\
\hline \multirow[t]{2}{*}{ Sweden } & $-0.839^{* * *}$ & $-0.855^{* * *}$ & $-0.275^{* * *}$ & $-0.269^{* * *}$ \\
\hline & $(0.061)$ & $(0.062)$ & $(0.079)$ & $(0.080)$ \\
\hline \multirow[t]{2}{*}{ Greece } & $0.200^{* * *}$ & $0.185^{* * *}$ & 0.019 & 0.011 \\
\hline & $(0.061)$ & $(0.061)$ & $(0.076)$ & $(0.076)$ \\
\hline \multirow[t]{2}{*}{ Portugal } & $-0.489^{* * *}$ & $-0.498^{* * *}$ & $-0.787^{* * *}$ & $-0.793^{* * *}$ \\
\hline & $(0.068)$ & $(0.068)$ & $(0.096)$ & $(0.097)$ \\
\hline Year Dummies & Yes & Yes & Yes & Yes \\
\hline Observations & 27,633 & 27,633 & 27,628 & 27,628 \\
\hline Pseudo R2 & 0.0578 & 0.0588 & 0.0618 & 0.0629 \\
\hline
\end{tabular}

Source: Gallup World Poll, 2010-2013.

Notes: All logistic regressions are for 2009-2012 and use country and year dummies and report robust standard errors (in parentheses). The dependent variable in Models (1) and (2) is experienced stress yesterday and experienced anger yesterday in Models (3) and (4). Household income is log-transformed and is in international dollars (ID), which allows comparisons across countries and time.

*** $p<0.01,{ }^{* *} p<0.05,{ }^{*} p<0.1$. 
Table 10 Retirement vs. late-life work, average treatment effect using propensity score matching

\begin{tabular}{|c|c|c|c|c|c|c|c|}
\hline \multicolumn{8}{|c|}{ Control group: voluntary part-time workers } \\
\hline \multirow[b]{2}{*}{ Outcome } & $\mathbf{N}$ & $\mathbf{N}$ & $\begin{array}{l}\text { Average } \\
\text { outcome }\end{array}$ & $\begin{array}{l}\text { Average } \\
\text { outcome }\end{array}$ & ATT & S.E. & t-stat \\
\hline & Treatment & Control & Treatment & Control & & & \\
\hline$\overline{\mathrm{BPL}}$ & 139 & 139 & 6.525 & 6.835 & -0.309 & 0.266 & -1.160 \\
\hline $\begin{array}{l}\text { Experienced } \\
\text { happiness yesterday }\end{array}$ & 137 & 137 & 0.686 & 0.839 & -0.153 & 0.051 & -3.020 \\
\hline Smiled a lot yesterday & 135 & 135 & 0.748 & 0.867 & -0.119 & 0.048 & -2.490 \\
\hline Experienced stress yesterday & 140 & 140 & 0.243 & 0.250 & -0.007 & 0.052 & -0.140 \\
\hline Experienced anger yesterday & 140 & 140 & 0.150 & 0.093 & 0.057 & 0.039 & 1.460 \\
\hline Satisfied with personal health & 140 & 140 & 0.686 & 0.850 & -0.164 & 0.050 & -3.310 \\
\hline Satisfied with freedom & 115 & 115 & 0.783 & 0.826 & -0.043 & 0.052 & -0.830 \\
\hline \multicolumn{8}{|c|}{ Control group: full-time employees } \\
\hline & $\mathbf{N}$ & $\mathbf{N}$ & $\begin{array}{l}\text { Average } \\
\text { outcome }\end{array}$ & $\begin{array}{l}\text { Average } \\
\text { outcome }\end{array}$ & ATT & S.E. & t-stat \\
\hline Outcome & Treatment & Control & Treatment & Control & & & \\
\hline $\mathrm{BPL}$ & 226 & 226 & 5.987 & 6.394 & -0.407 & 0.191 & -2.130 \\
\hline $\begin{array}{l}\text { Experienced } \\
\text { happiness yesterday }\end{array}$ & 228 & 228 & 0.689 & 0.789 & -0.101 & 0.041 & -2.460 \\
\hline Smiled a Lot yesterday & 224 & 224 & 0.714 & 0.795 & -0.080 & 0.041 & -1.980 \\
\hline Experienced stress yesterday & 229 & 229 & 0.314 & 0.371 & -0.057 & 0.044 & -1.280 \\
\hline Experienced anger yesterday & 228 & 228 & 0.184 & 0.193 & -0.009 & 0.037 & -0.240 \\
\hline Satisfied with personal health & 230 & 230 & 0.622 & 0.813 & -0.191 & 0.041 & -4.650 \\
\hline Satisfied with freedom & 209 & 209 & 0.737 & 0.751 & -0.014 & 0.043 & -0.340 \\
\hline \multicolumn{8}{|c|}{ Control group: self-employed } \\
\hline & $\mathbf{N}$ & $\mathbf{N}$ & $\begin{array}{l}\text { Average } \\
\text { outcome }\end{array}$ & $\begin{array}{l}\text { Average } \\
\text { outcome }\end{array}$ & ATT & S.E. & t-stat \\
\hline Outcome & Treatment & Control & Treatment & Control & & & \\
\hline$\overline{\mathrm{BPL}}$ & 112 & 112 & 5.616 & 5.973 & -0.357 & 0.303 & -1.180 \\
\hline $\begin{array}{l}\text { Experienced } \\
\text { happiness yesterday }\end{array}$ & 111 & 111 & 0.676 & 0.712 & -0.036 & 0.062 & -0.580 \\
\hline Smiled a lot yesterday & 111 & 111 & 0.730 & 0.667 & 0.063 & 0.062 & 1.020 \\
\hline Experienced stress yesterday & 110 & 110 & 0.291 & 0.345 & -0.055 & 0.063 & -0.870 \\
\hline Experienced anger yesterday & 111 & 111 & 0.153 & 0.189 & -0.036 & 0.051 & -0.710 \\
\hline Satisfied with personal health & 112 & 112 & 0.714 & 0.804 & -0.089 & 0.057 & -1.560 \\
\hline Satisfied with freedom & 101 & 101 & 0.693 & 0.624 & 0.069 & 0.067 & 1.040 \\
\hline \multicolumn{8}{|c|}{ Control group: involuntary part-time workers } \\
\hline & $\mathbf{N}$ & $\mathrm{N}$ & $\begin{array}{l}\text { Average } \\
\text { outcome }\end{array}$ & $\begin{array}{l}\text { Average } \\
\text { outcome }\end{array}$ & ATT & S.E. & t-stat \\
\hline Outcome & Treatment & Control & Treatment & Control & & & \\
\hline$\overline{\mathrm{BPL}}$ & 62 & 62 & 6.806 & 6.226 & 0.581 & 0.440 & 1.320 \\
\hline $\begin{array}{l}\text { Experienced } \\
\text { happiness yesterday }\end{array}$ & 61 & 61 & 0.836 & 0.869 & -0.033 & 0.065 & -0.510 \\
\hline Smiled a lot yesterday & 61 & 61 & 0.803 & 0.738 & 0.066 & 0.077 & 0.860 \\
\hline Experienced stress yesterday & 62 & 62 & 0.274 & 0.403 & -0.129 & 0.085 & -1.520 \\
\hline
\end{tabular}


Table 10 Retirement vs. late-life work, average treatment effect using propensity score matching (Continued)

\begin{tabular}{|c|c|c|c|c|c|c|c|}
\hline Experienced anger yesterday & 62 & 62 & 0.145 & 0.210 & -0.065 & 0.069 & -0.940 \\
\hline Satisfied with personal health & 61 & 61 & 0.705 & 0.902 & -0.197 & 0.070 & -2.800 \\
\hline Satisfied with freedom & 53 & 53 & 0.698 & 0.755 & -0.057 & 0.087 & -0.650 \\
\hline
\end{tabular}

Source: Gallup World Poll, 2010-2011.

Notes: Summary of results from caliper propensity score matching. The treatment group is the group of retirees. The control group is the voluntary part-time workers in the top panel, followed by the full-time employees, the self-employed, and the part-time workers in the bottom panel. The number of observations refers to observations in the treatment and control groups in the common support area. Covariates used for matching (and satisfying the balancing property) are: age, gender whether the respondent is married, an interaction term for marriage and gender, whether the respondent has at least high school education, whether religion is important in the respondent's life, country, and year.

While PSM is useful in teasing out the causal relationship between retirement and SWB, the results should be treated with caution, as the matching is as good as the available matching covariates. Similarly, the t-statistics reported in Table 10 are computed using assumptions such as normal distributions of the variables, among others, and are very sensitive to sample size.

The top panel in Table 10 shows unequivocal differences between the retired and their non-retired voluntary part-time counterparts (who are of similar age, gender, education, religiosity, marital status and live in the same country). While the latter had on average higher evaluative well-being than the retired, the difference is statistically insignificant $(\mathrm{t}$-stat $=1.160)$. There is a statistically significant difference in favor of voluntary part-time workers for both happiness yesterday and smiling. There are no significant differences between the groups with respect to experiencing stress and anger the day before. Late-life workers are also more satisfied with their personal health and their freedom in life but the latter difference is statistically insignificant.

The second panel in Table 10 uses a different control group for the retirees -identical full-time workers. Based on these results, non-retired full-timers have significantly higher evaluative well-being (BPL) and positive hedonic well-being (smiling and happiness) than their retired counterparts. While most of the other differences are not statistically significant, the full-timers had higher health satisfaction. There are no statistically significant differences between the retirees and their non-retired self-employed counterparts (Table 10 third panel), meanwhile. This finding could be due to the fact that both the retired and the self-employed older workers face similar freedoms and constraints related to free time and activities. In addition, older workers for whom part-time work is not available may be choosing self-employment in preparation for retirement and may therefore have similar well-being outcomes as their retired counterparts. Finally, the bottom panel shows that the involuntarily employed part-time non-retirees are more satisfied with their health than retirees. These results furnish empirical evidence that late-life work has positive well-being effects, especially in terms voluntary work or full-time work for an employer.

The control groups - i.e., full-time workers, part-time workers, and the selfemployed - are proxies for an underlying latent variable - desired working time. The extant studies have assumed that because they prefer shorter working hours, older workers may retire earlier than planned if their employer does allow with such flexibility. Using longitudinal data from the UK, Bell and Rutherford (2013) show that while the overemployed older workers prefer to reduce their working hours, there is a substantial number of underemployed old works who would like to work longer hours. In addition, 
the self-employed older workers are much more likely to want to adjust their work hours and wages than the employed (Bell and Rutherford 2013). Our data allow us to complement this analysis by providing well-being comparisons between voluntary and involuntary part-time workers. In many countries, older workers face discrimination and involuntarily choose early retirement (Dorn and Sousa-Poza 2008). To supplement their income, they become "necessity" entrepreneurs and experience dissatisfaction (Block and Koellinger 2009). While our findings suggest that the retired fare worse than their voluntarily full-time and part-time counterparts along a number of well-being dimensions, there is no well-being premium for involuntary work and self-employment compared to retirement.

\section{Conclusion}

Building on research on the well-being effects of unemployment, late-life work, and job satisfaction, we explored the effects of different employment status and retirement arrangements on well-being. Our analysis covered a range of age cohorts and a number of European countries and the United States. While we confirm the well-known negative effects of unemployment on well-being, we have novel results on the different employment arrangements. The most important of these are the seeming well-being benefits to voluntary part-time employment as well as to remaining in the workforce beyond retirement age. Both sets of results were more robust in countries where parttime work is more likely to be the norm and/or where post retirement age work was likely to be voluntary.

Voluntary part-time workers had higher levels of evaluative and hedonic well-being, as well as lower levels of stress and anger than full-time workers. They were also more likely to report that they were satisfied with their jobs. Older workers who are self-employed, meanwhile, were more likely to report having an ideal job than were other cohorts. Furthermore, our propensity score matching estimation, which compared retired workers with observably similar late-life workers, found significant benefits for those who continued working. Older cohorts who remained in the labor force under full-time and voluntary parttime arrangements had higher levels of well-being and health satisfaction and lower levels of stress and anger than their retired counterparts.

Our results challenge the traditional model of full-time work and timely retirement, and suggest that flexible work arrangements (either full- or part-time) later in life may have significant well-being benefits. We hope that these results will inform the discussion about the potential benefits of flexible work and retirement arrangements, both in terms of fiscal burdens and the well-being of citizens. In addition to the administrative and implementation costs, changing employment and retirement schemes and allowing more labor market flexibility will likely have transactions costs, at least in the short run. For example, both employers and employees may face bargaining costs related to negotiating the flexible work arrangements which are optimal for both sides. Employers may moreover incur additional costs related to restructuring tasks to accommodate part-time work. Yet, the long-run fiscal benefits, as well as those to aggregate wellbeing - which our results suggest are quite large - make such policy changes worth considering in many countries. While this analysis is limited to Europe and the U.S., it may also have implications for other countries. 


\section{Endnotes}

${ }^{1}$ While there have been extensive labor market reforms in Europe in the past two decades, they have primarily focused on temporary and fixed-contract work (Dawson and Veliziotis 2013).

${ }^{2}$ If young and old workers are complements, however, extending the retirement age may in fact increase the demand for younger workers, their employment levels, and their wages.

${ }^{3}$ Specifically, our analyses using quantile regressions show that the well-being of the happiest individuals does not depend on employment. Quantile evaluative well-being regression results are available upon request.

${ }^{4}$ Wottiez and Theeuwes (1998) show that early retirees (ages 43-63) in Holland have higher life satisfaction levels than workers but normal-aged retirees may be unhappier than workers. In Denmark, retirement seems to have no effect on women's well-being but reduces men's well-being (Jaeger and Holm 2004). Latif (2011) finds a positive effect of retirement on hedonic happiness in Canada; using panel data from Germany, Bonsang and Klein (2012) find that while the effect of retirement on life satisfaction is negligible and income satisfaction decreases, satisfaction with free time increases. Studies document the negative well-being effects of involuntary retirement in Germany (Bonsang and Klein, 2012) and the U.S. (Bender 2012; Calvo et al. 2009). Calvo (2006) shows that late-life work is positive for well-being overall, but undesirable work (i.e., jobs that have excessive demands or cause dissatisfaction) impacts moods and mortality.

${ }^{5}$ Life satisfaction and morale among male retirees, for example, increase during the first years of retirement (Kim and Moen 2002; Gall et al. 1997) possibly because retirees take advantage of their free time to pursue their interests and hobbies. Continuous retirement, however, leads to an increase in depressive symptoms among males in the Untied States (Kim and Moen 2002).

${ }^{6}$ See Dawson and Veliziotis (2013) on the relationship between temporary employment, job security, and SWB in Britain.

${ }^{7}$ Research from the British Household Panel shows that a partner's presence during the interview increased the likelihood of underreporting job satisfaction while the presence of children increased the likelihood of overreporting it for women (Conti and Pudney 2011). We do not have a variable for whether the partner or children were present at the time of the interview and could only imperfectly control for audience effects by including controls for household size, whether the respondent is de facto married, and has children in the household.

${ }^{8}$ This phenomenon was originally identified in research by Michael Marmot, a British epidemiologist, who found that high status civil servants lived much longer than low status civil servants; both worked in a very rigid hierarchy with little avenue for advancement.

${ }^{9}$ While PSM matches only on observables, it also matches on unobservables to the extent that they are correlated with the matching covariates (Stuart 2010).

${ }^{10}$ Blundell and Costa Dias (2000) Caliendo and Kopeinig (2008) Deheja and Wahba (2002), Rosenbaum and Rubin (1983), Smith and Todd (2005), Stuart (2010), and Todd (2006) furnish detailed overviews of the theoretical, practical, and methodological details pertaining to Propensity Score Matching (PSM). 
${ }^{11}$ We used Stata's user-written -psmatch2- module to implement the matching (Leuven and Sianesi 2003).

${ }^{12}$ Summary statistics of employment status by age and country are available upon request.

${ }^{13}$ Detailed statistics for each well-being dimension by country are available upon request.

${ }^{14}$ Respondents in Sweden and the U.S. had the highest average BPL scores (7.4 and 7.3, respectively), while those in Portugal (5.2) and Turkey (5.5) had the lowest. The voluntarily employed part-time workers in the U.S. and Sweden had the highest average BPL scores, while participants in Portugal scored the lowest on this well-being dimension. Results available upon request.

${ }^{15}$ Overall, the UK, Germany, and the U.S. had the highest proportions of respondents reporting happiness, while Greece had the lowest. Among the group of voluntarily employed part-time workers, the U.S. and the UK had the highest proportions of respondents reporting having experienced happiness yesterday, while Greece had the lowest proportion. Results available upon request.

${ }^{16}$ Among the voluntarily employed part-time, the most stressed respondents were again in Turkey, while the least stressed were in Sweden. Results available upon request.

${ }^{17}$ The Swedes (93 percent) and Germans (91 percent) were the most satisfied, while the Greeks (78 percent) and the Turks (77 percent) had the lowest job satisfaction rates. The U.S., the UK, Spain, Sweden, and Germany were among the countries with the highest proportion of voluntary part-time workers who were satisfied with their jobs. Results available upon request.

${ }^{18}$ Respondents in Sweden, Portugal, and Germany most likely to report so, while those in Greece, Spain, and Turkey least likely to report so. Among the voluntarily part-time workers, those in the US and Sweden were most likely to report that their current job was the ideal one for them, while those in Italy and Greece were least likely to report so. Results available upon request.

${ }^{19}$ The BPL regression equations are estimated using both standard logistic regressions as well as using heterogeneous choice models, which control for across-group heterogeneity inherent in logistic models (Williams 2009). We only report the standard ordered logit results as the heterogeneous choice results are similar.

${ }^{20}$ The job satisfaction regressions may suffer from selection bias as job satisfaction is observed only for those who work. We performed a Heckman probit correction (using the number of children in the household as the additional variable in the selection equation). The rho statistics were not statistically significant, suggesting that unobservables affecting labor market participation do not correlate with unobservables affecting job satisfaction. Likewise, the likelihood ratio test had a p-value of 0.430 for the job satisfaction regression and a p-value of 0.124 for the ideal job regression; we do not reject the null hypothesis that the outcome equation (job satisfaction) is uncorrelated with the selection equation. In other words, selection bias is not a problem in this instance, and we can be confident in our logit estimates.

${ }^{21}$ We checked whether the balancing property was satisfied using t-tests for the equality of means for the key covariates after matching (See Table 1 for BPL). We also calculated the mean standardized bias before and after matching (Table 2). The 
balancing tests for the rest of the dependent variables are available upon request. In all cases, the t-tests are statistically insignificant and the mean bias is at most 8.5 , suggesting that the matching was successful.

\section{Competing interests}

The IZA Journal of European Labor Studies is committed to the IZA Guiding Principles of Research Integrity. The authors declare that they have observed these principles.

\section{Acknowledgements}

The authors would like to thank Kemal Derviş for inspiring this project and for early collaboration. Responsible editor: Alan Barrett

Received: 26 September 2013 Accepted: 9 January 2014

Published: 04 Mar 2014

\section{References}

Aaron H, Burtless G (eds) (2013) Closing the Deficit: How Much Can Later Retirement Help? The Brookings Instiutution Press, Washington, D.C

Aguilar AC, Garcia Munoz TM, Moro-Egido A (2013) Heterogeneous Self-employment and Satisfaction in Latin America. J Econ Psychol 39:44-61

Bell DN, Rutherford AC (2013) Older workers and working time. IZA Discussion Paper 7546. http://ftp.iza.org/dp7546.pdf. Accessed December 202013

Bender KA (2012) An analysis of well-being in retirement: The role of pensions, health, and "voluntariness" of retirement. J Socio-Econ 41(4):424-433. doi:10.1016/j.socec.2011.05.010

Benz M, Frey BS (2008) The value of doing what you like: Evidence from the self-employed in 23 countries. J Econ Behav Organ 68(3,Äi4):445-455. doi:10.1016/j.jebo.2006.10.014

Binder M, Coad A (2011) From average Joe's happiness to miserable jane and cheerful john: using quantile regressions to analyze the full subjective well-being distribution. J Econ Behav Organ 79(3):275-290. doi:10.1016/j.jebo.2011.02.005

Block J, Koellinger P (2009) I Can't Get No satisfaction-necessity entrepreneurship and procedural utility. Kyklos 62(2):191-209. doi:10.1111/j.1467-6435.2009.00431.x

Blundell R, Costa Dias M (2000) Evaluation methods for Non-experimental data. Fisc Stud 21(4):427-468. doi:10.1111/j.1475-5890.2000.tb00031.x

Bonsang E, Klein TJ (2012) Retirement and subjective well-being. J Econ Behav Organ 83(3):311-329. doi:10.1016/j.jebo.2012.06.002

Burtless G (2013) The Impact of Population Aging and Delayed Retirement on Workforce Productivity. Center for Retirement Research at Boston College Working Paper 2013-11, pp 1-45. http://crr.bc.edu/wp-content/uploads/ 2013/05/wp 2013-111.pdf Accessed December 232013

Caliendo M, Kopeinig S (2008) Some practical guidance for the implementation of propensity score matching. J Econ Surv 22(1):31-72. doi:10.1111/j.1467-6419.2007.00527.x

Calvo E (2006) Does Working Longer Make People Healthier and Happier? MPRA Paper No 5606, pp 1-9. http://mpra.ub.uni-muenchen.de/5606/ Accessed September 232013

Calvo E, Haverstick K, Sass SA (2009) Gradual retirement, sense of control, and Retirees' happiness. Res Aging 31(1):112-135. doi:10.1177/0164027508324704

Carstensen LL, Turan B, Scheibe S, Ram N, Ersner-Hershfield H, Samanez-Larkin GR, Brooks KP, Nesselroade JR (2011) Emotional experience improves with age: evidence based on over 10 years of experience sampling. Psychology Aging 26(1):21-33

Clark A (2003) Unemployment as a social norm: psychological evidence from panel data. J Labor Econ 21(2):323-351. doi:10.1086/345560

Clark A, Oswald A (1994) Unhappiness and unemployment. Econ J 104(424):648-659. doi:10.2307/2234639

Clark A, Georgellis Y, Sanfey P (2001) Scarring: the psychological impact of past unemployment. Economica 68 (270):221-241

Clark A, Knabe A, Ratzel S (2010) Boon or bane? Others' unemployment, well-being and job insecurity. Labour Econ 17(1):52-61. doi:10.1016/j.labeco.2009.05.007

Conti G, Pudney S (2011) Survey design and the analysis of satisfaction. Rev Econ Stat 93(3):1087-1093

Dawson C, Veliziotis M (2013) Temporary employment, job satisfaction and subjective well-being. Univesrity of the West of England Economics Working Paper Series 1309, pp 1-23. http://ideas.repec.org/p/uwe/wpaper/20131309.html Accessed August 232013

Dehejia RH, Wahba S (2002) Propensity score-matching methods for nonexperimental causal studies. Rev Econ Stat 84(1):151-161. doi:10.1162/003465302317331982

Derviş K (2013) The Next Social Contract. Project Syndicate. http://www.project-syndicate.org/commentary/redefiningthe-life-of-work-by-kemal-dervi. Accessed July 172013

Diener E, Suh EM, Lucas RE, Smith HL (1999) Subjective well-being: three decades of progress. Psychol Bull 125(2):276-302. doi:10.1037/0033-2909.125.2.276

Diener E, Inglehart R, Tay L (2012) Theory and Validity of Life Satisfaction Scales. Social Indicators Research:1-31. doi:10.1007/s11205-012-0076-y

DiTella R, MacCulloch RJ, Oswald A (2001) Preferences over inflation and unemployment: evidence from surveys of happiness. Am Econ Rev 91(1):335-341. doi:10.2307/2677914

Dolan P, Kavetsos G (2012) Happy Talk: Mode of Administration Effects on Subjective Well-Being. Centre for Economic Performance Discussion Paper No 1159, pp 1-17 
Dolan P, Peasgood T, White M (2008) Do we really know what makes us happy? A review of the economic literature on the factors associated with subjective well-being. J Econ Psychol 29(1):94-122

Dorn D, Sousa-Poza A (2008) 'Voluntary' and 'involuntary' early retirement: an international analysis. Appl Econ 42(4):427-438. doi:10.1080/00036840701663277

Eggers A, Gaddy C, Graham C (2006) Well-being and unemployment in Russia in the 1990s: Can society's suffering be individuals' solace? J Socio-Econ 35(2):209-242. doi:10.1016/j.socec.2005.11.059

Erdogan B, Bauer TN, Truxillo DM, Mansfield LR (2012) Whistle while You work: a review of the life satisfaction literature. J Manag 38(4):1038-1083. doi:10.1177/0149206311429379

Fisher BJ (1995) Successful aging, life satisfaction, and generativity in later life. Int J Aging Hum Dev 41(3):239-250

Frey B (2008) Happiness: A Revolution in Economics. The MIT Press, Boston

Gall TL, Evans DR, Howard J (1997) The retirement adjustment process: changes in the well-being of male retirees across time. J Gerontol B Psychol Sci Soc Sci 52B(3):P110-P117. doi:10.1093/geronb/52B.3.P110

Graham C (2009) Happiness Around the World: The Paradox of Happy Peasants and Miserable Millionaires. Oxford University Press, New York, NY

Graham C (2012) The Distinctiveness of Hedonic and Evaluative Well-being. Background Paper for the National Academy of Sciences Panel on Well-being Metrics and Public Policy. The Brookings Institution, Washington, DC

Graham C, Felton A (2006) Inequality and happiness: insights from Latin America. J Econ Inequal 4(1):107-122

Graham C, Nikolova M (2013) Happy Peasants and Frustrated Achievers? Agency, Capabilities, and Subjective Well-being Working Paper. The Brookings Institution, Washington, DC

Graham C, Pettinato S (2002) Frustrated achievers: winners, losers and subjective well-being in New market economies. J Dev Stud 38(4):100-140. doi:10.1080/00220380412331322431

Grogan L, Koka K (2013) Economic crises and wellbeing: Social norms and home production. J Econ Beh Organ 92(0):241-258. doi:10.1016/j.jebo.2013.05.007

Heinrich C, Maffioli A, Vazquez G (2010) A Primer for Applying Propensity-Score Matching: Impact-Evaluation Guidelines. Office of Strategic Planning and Development Effectiveness, Inter-American Development Bank, pp 1-56. http://ideas.repec.org/p/idb/spdwps/1005.html Accessed December 232013

Helliwell JF, Barrington-Leigh CP, Harris A, Huang H (2010) In: Diener JFH E, Kahneman D (ed) International Differences in Well-Being. Oxford University Press, New York

Hetschko C, Knabe A, Schöb R (2013) Changing identity: retiring from unemployment. The Economic Journal:n/a-n/a. doi:10.1111/ecoj.12046

Jaeger MM, Holm A (2004) How stressful is retirement? New evidence from a longitudinal, fixed-effects analysis. Center for applied microeconomics, Copenhagen, Denmark

Kahneman D, Deaton A (2010) High income improves evaluation of life but not emotional well-being. Proc Natl Acad Sci 107(38):16489-16493. doi:10.1073/pnas.1011492107

Kahneman D, Krueger AB (2006) Developments in the measurement of subjective well-being. J Econ Perspect 20(1):3-24

Kim JE, Moen P (2002) Retirement transitions, gender, and psychological well-being: a life-course, ecological model. J Gerontol B Psychol Sci Soc Sci 57(3):P212-P222. doi:10.1093/geronb/57.3.P212

Knabe A, Rätzel S (2010) Better an insecure job than no job at all? Unemployment, job insecurity and subjective wellbeing. Econ Bull 30(3):2486-2494

Knabe A, Rätzel S, Schöb R, Weimann J (2010) Dissatisfied with life but having a good Day: time-use and well-being of the unemployed*. Econ J 120(547):867-889. doi:10.1111/j.1468-0297.2009.02347.x

Krueger AB, Mueller A, Davis SJ, Sahin A (2011) Job Search, Emotional Well-Being, and Job Finding in a Period of Mass Unemployment: Evidence from High Frequency Longitudinal Data [with Comments and Discussion]. Brookings Papers on Economic Activity, Economic Studies Program, The Brookings Institution. 42(1). Spring

Latif E (2011) The impact of retirement on psychological well-being in Canada. J Socio-Econ 40(4):373-380. doi:10.1016/j.socec.2010.12.011

Leuven E, Sianesi B (2003) PSMATCH2: Stata module to perform full Mahalanobis and propensity score matching, common support graphing, and covariate imbalance testing. Statistical Software Components; Boston College Department of Economics. http://ideas.repec.org/c/boc/bocode/s432001.html Accessed December 232013

Lucas R (2007) Adaptation and the Set-point model of subjective well-being. Curr Dir Psychol Sci 16(2):75-79

Lucas RE, Clark AE, Georgellis Y, Diener E (2004) Unemployment alters the set point for life satisfaction. Psychol Sci 15(1):8-13

OECD (2013) OECD Employment Outlook 2013. http:/dx.doi.org/10.1787/empl_outlook-2013-en. Accessed September 182013

Peikes DN, Moreno L, Orzol SM (2008) Propensity score matching. Am Stat 62(3):222-231. doi:10.1198/ $000313008 \times 332016$

Powdthavee N (2007) Are there geographical variations in the psychological cost of unemployment in south africa? Soc Indic Res 80(3):629-652. doi:10.2307/27734557

Ravallion M, Lokshin M (2001) Identifying welfare effects from subjective questions. Economica 68(271):335-357

Rosenbaum PR, Rubin DB (1983) The central role of the propensity score in observational studies for causal effects. Biometrika 70(1):41-55

Shields MA, Price SW (2005) Exploring the economic and social determinants of psychological well, Äêbeing and perceived social support in England. J R Stat Soc A Stat Soc 168(3):513-537

Shields MA, Price SW, Wooden M (2009) Life satisfaction and the economic and social characteristics of neighbourhoods. J Popul Econ 22(2):421-443. doi:10.2307/40344738

Smith JA, Todd PA (2005) Does matching overcome LaLonde's critique of nonexperimental estimators? Journal of econometrics 125(1):305-353

Steiner PM, Cook TD, Shadish WR, Clark MH (2010) The importance of covariate selection in controlling for selection bias in observational studies. Psychol Methods 15(3):250-267. doi:10.1037/a0018719

Steiner PM, Cook TD, Shadish WR (2011) On the importance of reliable covariate measurement in selection bias adjustments using propensity scores. J Educ Behav Stat 36(2):213-236. doi:10.3102/1076998610375835

Stuart EA (2010) Matching methods for causal inference: A review and a look forward. Statistical science: a review journal of the Institute of Mathematical Statistics 25(1):1 
Stutzer A, Lalive R (2004) The role of social work norms in Job searching and subjective well-being. J Eur Econ Assoc 2(4):696-719. doi:10.2307/40004878

Thoma M (2013) Where Do Older Workers Work the Most? http://economistsview.typepad.com/economistsview/2013/ 07/where-do-older-workers-work-the-most.html. Accessed August 102013

Todd P (2006) Matching Estimators. http://athena.sas.upenn.edu/ petra/papers/mpalgrave2.pdf. Accessed December 162013

vanDalen HP, Henkens K, Henderikse W, Schippers J (2010) Do European employers support later retirement? Int J Manpow 31(3):360-373

Velasquez-Manoff M (2013) Status and Stress. http://opinionator.blogs.nytimes.com/2013/07/27/status-and-stress/. Accessed July 272013

Wang M (2007) Profiling retirees in the retirement transition and adjustment process: Examining the longitudinal change patterns of retirees' psychological well-being. J Appl Psychol 92(2):455-474. doi:10.1037/0021-9010.92.2.455

Williams R (2009) Using heterogeneous choice models to compare logit and probit coefficients across groups. Sociol Methods Res 37(4):531-559

Winkelmann L, Winkelmann R (1998) Why are the unemployed so unhappy? Evidence from panel data. Economica 65(257):1-15

Wottiez I, Theeuwes J (1998) 9 Well-being and labor market status. In: Jenkins SP, Kapteyn A, van Praag BMS (ed) The distribution of welfare and household production: International perspectives. Cambridge University Press, Cambridge, pp 211-230

10.1186/2193-9012-3-5

Cite this article as: Nikolova and Graham: Employment, late-life work, retirement, and

well-being in Europe and the United States. IZA Journal of European Labor Studies 2014, 3:5

Submit your manuscript to a SpringerOpen ${ }^{\circ}$ journal and benefit from:

- Convenient online submission

- Rigorous peer review

- Immediate publication on acceptance

- Open access: articles freely available online

High visibility within the field

Retaining the copyright to your article

Submit your next manuscript at $\gg$ springeropen.com 